\title{
Leonard Bernstein's Jewish Boston: Cross- Disciplinary Research in the Classroom
}

\section{Citation}

Oja, Carol J. and Kay Kaufman Shelemay. 2009. Leonard Bernstein's Jewish Boston: CrossDisciplinary research in the classroom. Journal of the Society for American Music 3(1): 3-33.

\section{Published Version}

http://dx.doi.org/10.1017/S1752196309090026

\section{Permanent link}

http://nrs.harvard.edu/urn-3:HUL.InstRepos:2623650

\section{Terms of Use}

This article was downloaded from Harvard University's DASH repository, and is made available under the terms and conditions applicable to Other Posted Material, as set forth at http:// nrs.harvard.edu/urn-3:HUL.InstRepos:dash.current.terms-of-use\#LAA

\section{Share Your Story}

The Harvard community has made this article openly available.

Please share how this access benefits you. Submit a story.

Accessibility 


\title{
Leonard Bernstein's Jewish Boston: Cross-Disciplinary Research in the Classroom
}

\author{
CAROL J. OJA AND KAY KAUFMAN SHELEMAY
}

\begin{abstract}
Leonard Bernstein is most often perceived as the quintessential New Yorker-music director of the New York Philharmonic from 1958 to 1969 and composer of Broadway shows that made New York their focus. Yet his grounding in the greater Boston area was powerful. He was born in 1918 in Lawrence, Massachusetts, and raised in various Jewish neighborhoods within Boston. The young Leonard went to Boston Latin, a prestigious public prep school, and graduated from Harvard in 1939.

This article explores a team research project, made up of Harvard graduate students and undergraduates, which delved into the urban subcultures and post-immigrant experiences that shaped Bernstein's youth and early adulthood. It considers the synergy between an individual and a community, and it examines the complexities of blending pedagogy with research, analyzing the multilayered methodologies and theoretical strategies that were employed.

Given Bernstein's iconic status, his life and career illuminate a broad range of questions about the nature of music in American society. Fusing the techniques of ethnographic and archival research, our team probed Bernstein's formative connections to Jewish traditions through his family synagogue (Congregation Mishkan Tefila), the ethnic geography that defined the Boston neighborhoods of his immigrant family, the network of young people involved in Bernstein's summer theatrical productions in Sharon, Massachusetts, during the 1930s, and the formative role of the city's musical venues and institutions in shaping Bernstein's lifelong campaign to collapse traditional distinctions between high and low culture.
\end{abstract}

The classroom most often represents a separate sphere from active research. Yet with the right topic and set of circumstances, the two can enter into a wonderfully productive relationship. This synchronicity certainly was the case with a seminar focused on Leonard Bernstein's Boston years, which we taught at Harvard University in the spring semester of 2006. It centered on Bernstein's formative experiences within Boston's Jewish immigrant community in the decades immediately before World War II. With community-based research as a bedrock principle, we seized the opportunity to study how this now-legendary musician interacted with local musical, religious, and educational communities. Given the length of time since Bernstein's birth in 1918, any remaining opportunities for ethnographic interviews were rapidly diminishing.

From the beginning we were aware that Bernstein's hydra-headed talents-not just as conductor and composer, but also as teacher, writer, television personality, and overall cultural celebrity-opened a window on considerations that transcend our separate specializations in ethnomusicology and historical musicology, as well as current norms for their practice in the public domain. In other words, this project became an opportunity to put interdisciplinarity into action.

As an iconic figure, Bernstein's life and career provide many potential answers to the widest range of questions about the nature of music in society. They also reveal much about the distinctiveness of individual urban areas and the subcultural 
groups within them. The multifaceted quality of Bernstein's talents and career purposefully collapsed longstanding oppositions in Western music. He was a true crossover musician before the term was coined, and he constantly breached the divide between sacred and secular. Furthermore, Bernstein's life (like that of many American musicians) provides a case study in the impact of immigration and assimilation. His commitment to human rights and world peace manifested itself throughout his career; it is impossible to research his life and music without confronting his politics and activism on behalf of major causes. Studying Bernstein also provides a perspective on how the arts can become a means of building institutions and even nations. This activism is apparent through his work as conductor with the Palestine Symphony Orchestra (later the Israel Philharmonic), his teaching at the fledgling Brandeis University, and his role in founding music festivals with overt political agendas, such as the Pacific Music Festival, in Sapporo, Japan. Bernstein's story also offers a strikingly open book on the most deeply human aspects of musical creativity and its relationship to individual personality, social conventions, and matters of gender and sexuality. Finally, the broader trajectory of Bernstein's career and its residue in documents and human memory provide a case study in the construction of mythologies-an opportunity to delve more deeply into the crosscurrents of talent, personal ambition, business acumen, and charisma that gave rise to the twentieth-century's mega-stars.

The overarching Bernstein project launched by this course had multiple dimensions. Beyond involving students substantively through primary research, it set the stage for both a student-curated exhibit and the performance of little-known Bernstein compositions at "Leonard Bernstein: Boston To Broadway," a festival produced at Harvard during the fall of 2006; the festival was conceived in tandem with the seminar and had student participation at its core. ${ }^{1}$ Students also contributed research findings to the festival's program book, a sixty-four-page, heavily illustrated document. ${ }^{2}$

Both of us have led other team research projects in the past, and we drew heavily on those experiences to plan and teach the Bernstein seminar. ${ }^{3}$ Yet the Bernstein project

\footnotetext{
${ }^{1}$ The opening program of Harvard's Bernstein Festival was titled "Boston's Bernstein" and included the following (all performed by Harvard students): Y'vawrech'chaw, arranged by Solomon G. Braslavsky; Na-aleh L'artseinu, arranged by A. W. Binder; Piano Variations by Aaron Copland; "A Wandr'ing Minstrel I" from The Mikado by Sir William Gilbert and Sir Arthur Sullivan; "CroonSpoon" from The Cradle Will Rock by Marc Blitzstein; "Of Thee I Sing" from Of Thee I Sing by George and Ira Gershwin; Four-Hand Sonata by Harold Shapero; Yigdal by Leonard Bernstein; Simchu Na by Matityahu Weiner (arr. Bernstein); Seven Anniversaries by Bernstein; Rhapsody in Blue by George Gershwin (arr. Bernstein); Trio for Violin, Violoncello, and Piano by Bernstein. Judith Clurman conducted and curated the program.

${ }^{2}$ Leonard Bernstein - Boston to Broadway: Concerts and Symposia at Harvard University, Carol J. Oja and Judith Clurman, directors; Emily Abrams Ansari, program book editor (Cambridge, Mass.: Office for the Arts at Harvard and Harvard University Music Department, 2006). Hereinafter referred to as Harvard Bernstein Festival Program Book.

${ }^{3}$ Shelemay directed two team projects about which she has published articles, including a study of the music of Syrian Jews in Brooklyn carried out with students when she taught at New York University in the mid-1980s and a collaborative course in the mid-1990s with Harvard Music Department colleagues investigating the musicians of Boston's early music movement. See Kay Kaufman Shelemay, "Together in the Field: Team Research Among Syrian Jews in Brooklyn, New York," Ethnomusicology
} 
was much larger in its scale and scope, covering multiple sites and social groupings in the Jewish communities of Boston and Sharon, Massachusetts, as well as engaging with a number of institutions connected to Bernstein's youth (Boston Latin School, Boston Symphony Orchestra, Brandeis University, Harvard University, and New England Conservatory). Along the way, other networks emerged as integral to Bernstein's experience and as potential sources for our research, ranging from local piano instructors to members of the business community.

In this article we provide an overview of Bernstein's experiences in relation to these institutions and networks in the greater Boston area. Our main goals include discussing the rich pedagogical rewards of engaging students in team research about local history, outlining our methodology as a possible template for other such projects, and highlighting ways in which this venture contributed new-or nuanced-understandings of Bernstein. Even though our venture placed one luminous celebrity at its center, the core effort involved community-based research. By the end we had raised fresh questions about the sensibilities and creativity of a man who from his earliest years was acknowledged as being multitalented across the domains of musical performance, composition, and education.

\section{Child of Boston: A Biographical Sketch}

Leonard Bernstein (1918-90) is most often perceived as the quintessential New Yorker-music director of the New York Philharmonic from 1958 to 1969 and composer of Broadway shows, from On the Town to West Side Story, that not only brought innovations to Broadway but made New York their focus. Yet it does not take much digging to realize that Bernstein had a powerful grounding in the greater Boston area and that the tie remained strong throughout his life. His father, Samuel, and his mother, Jennie Resnick, were immigrants from towns in the Ukraine that were adjacent to the Polish border. Leonard was born in Lawrence, Massachusetts, where his mother's family lived, but was raised in various Jewish neighborhoods within greater Boston, moving from Mattapan to Allston, then Roxbury, and finally Newton, where his father built a house in 1932 (Fig. 1). In 1920 Sam Bernstein joined Roxbury's Congregation Mishkan Tefila, a Conservative synagogue, which was one of the oldest temples in the Boston area and was made up of upwardly mobile Jews who prided themselves on their strong musical and artistic traditions.

After elementary school, the young Leonard went to Boston Latin School, a prestigious public prep school, and later graduated from Harvard in 1939. By attending Boston Latin and then Harvard, Bernstein followed what in the first

32/3 (1988): 369-84; "Toward an Ethnomusicology of the Early Music Movement: Thoughts on Bridging Disciplines and Musical Worlds," Ethnomusicology 45/1 (Winter 2001): 1-29. Oja mounted a team project at the College of William and Mary surrounding Music of Williamsburg (1960), a film about musical life in eighteenth-century Virginia that was curated by Alan Lomax. It raised fascinating questions about race and the telling of history. See Carol J. Oja, "Filming the Music of Williamsburg with Alan Lomax," Institute for Studies in American Music Newsletter 23/1 (Fall 2003): 1-2, 12-13. 


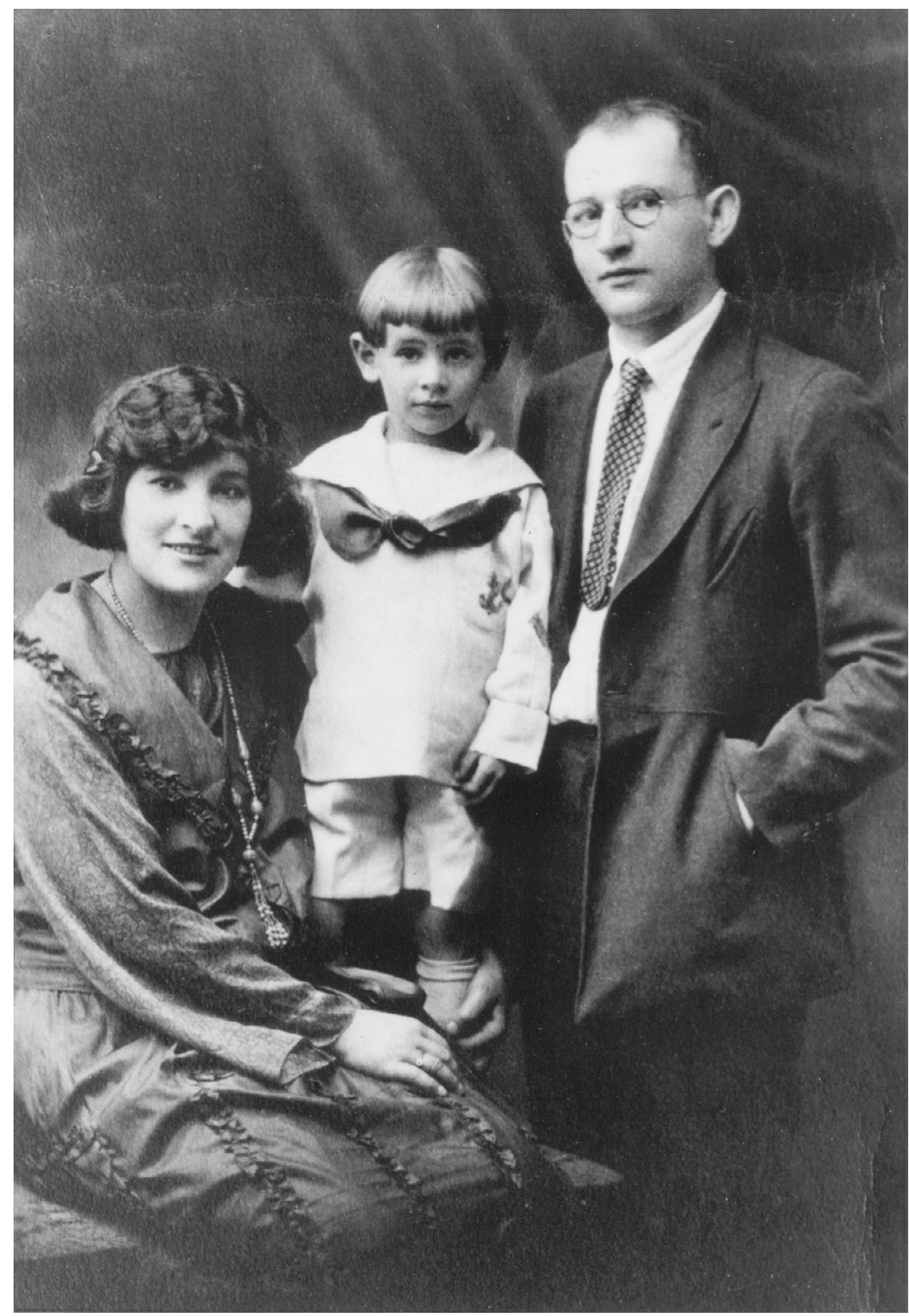

Figure 1. Leonard Bernstein as a toddler, with his parents Samuel and Jennie (ca. 1920). Photographer unknown. Leonard Bernstein Collection, Music Division, Library of Congress.

decades of the twentieth century was the path for the most talented and upwardly mobile young Jewish men in the Boston area (Fig. 2). ${ }^{4}$

${ }^{4}$ The important role of the Boston Latin School in educating upwardly mobile Jews is discussed briefly in: Jonathan Sarna, "The Jews of Boston in Historical Perspective," in The Jews of Boston, ed. Jonathan D. Sarna, Ellen Smith, and Scott-Martin Kosovsky (New Haven, Conn.: Yale University Press, [1995] 2005), 13. 


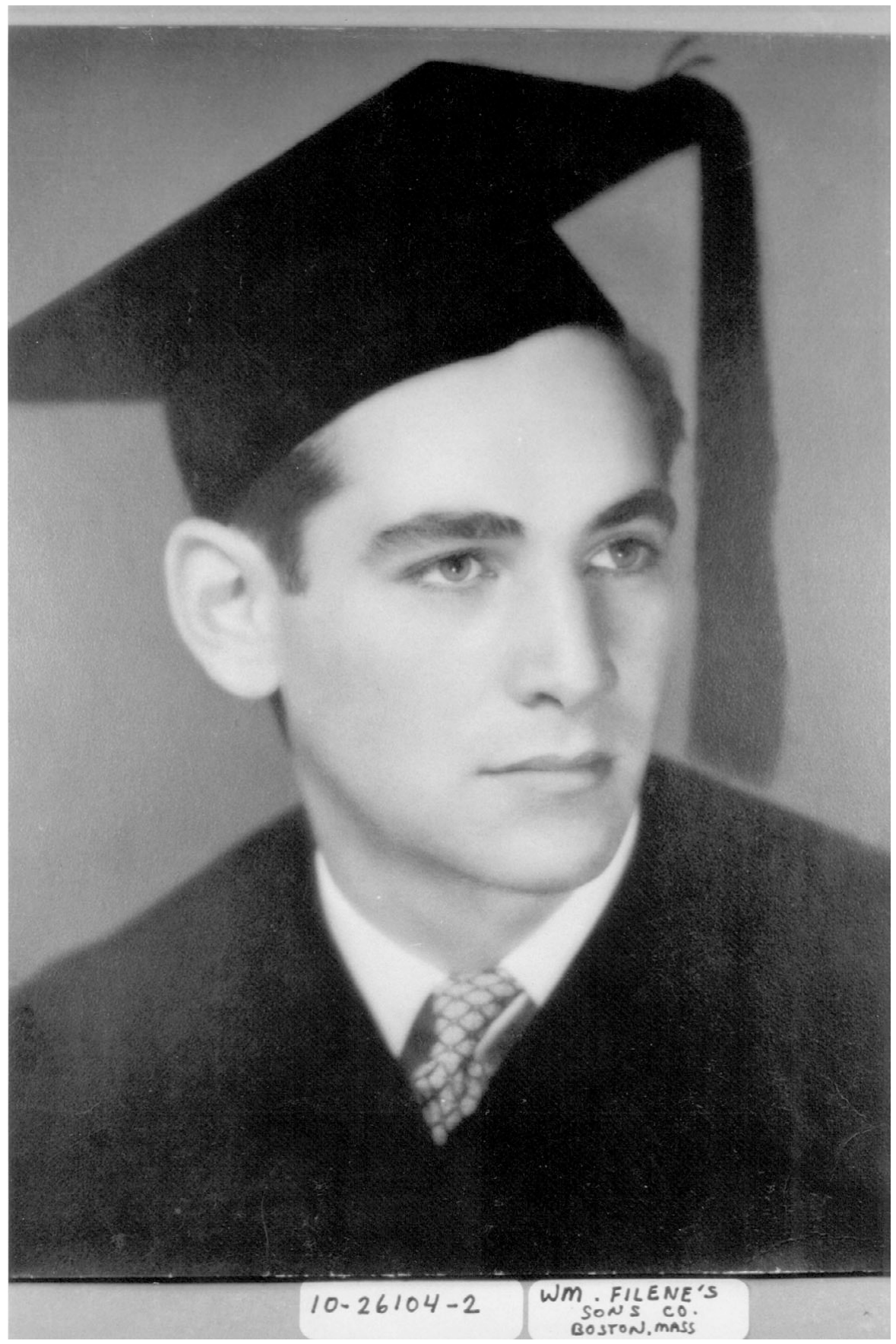

Figure 2. Leonard's Harvard graduation picture from 1939. Photographer: William Filene's Sons Company, Boston, Massachusetts. Leonard Bernstein Collection, Music Division, Library of Congress.

Over the years Bernstein returned to Boston frequently. His trips included visits to his parents and extended family, but they also involved ongoing relationships in multiple other arenas: a profound tie to the Boston Symphony Orchestra and 
its conductor, Serge Koussevitzky, as well as to Tanglewood from its earliest years; tryouts in Boston for most of his Broadway shows; and a continuing connection with the Congregation Mishkan Tefila, which moved to Chestnut Hill in the 1950s from its longtime location in Roxbury. Bernstein returned to Mishkan Tefila to celebrate major family rites of passage- his wedding in 1951 and the bar mitzvah of his son, Alexander, in $1968 .{ }^{5} \mathrm{He}$ also taught as a visiting professor at Brandeis during its formative years in the early 1950s. Thus Boston and its Jewish community assumed major roles not only in shaping Bernstein but also in sustaining him over time. The timeline provided in Appendix 1, compiled by doctoral student Emily Abrams Ansari, provides an overview of Bernstein's connections to people, places, and institutions in Boston.

The depth of Leonard's ties to Boston and to Massachusetts overall was made clear during one of the first interviews conducted by our seminar-in a session with his younger brother, Burton. A longtime staff writer for the New Yorker, Burton bore witness to Leonard's Boston roots by recalling his brother's final concert at Tanglewood in the summer of 1990:

Naturally the Jewish community in Boston really worshipped Lenny. He was nothing short of God brought down to earth. So Boston adored Lenny, and the feeling was always mutual and reciprocal right to the end. And it was only fitting, that that last concert I remember on that cold, August afternoon - a rainy afternoon in 1990 which turned out to be his last concert and his last public appearance ever-was at Tanglewood with the Boston Symphony Orchestra. His beloved Boston Symphony Orchestra. And remember Tanglewood is really kind of an extension of Boston. I mean, it is Boston, in effect, but it's some miles away. And for those who were there, it was one helluva concert-the weather notwithstanding. It was even a mythic concert. When I think about it now, it was like Lenny coming home to die, so to speak. He was coming home to a real home, and he knew deep down that was it.... A couple months later he died. ${ }^{6}$

Thus it was clear from early on that both Bernstein and Boston were our subjects and that the close and symbiotic relationship between this man and the urban area from which he came would provide rich materials for study. The challenge was how to organize the multiple dimensions of a daunting research venture.

\section{Designing Team Research}

We started devising the project well over a year before the class began by making connections with Congregation Mishkan Tefila, which presented extraordinary opportunities for both archival and ethnographic research; with the Leonard Bernstein Office in New York; and with the Bernstein family. Leonard Bernstein, although deceased since 1990, remains very much a presence at Mishkan Tefila, growing out of his father Sam's longtime association beginning in its early days in Roxbury. During the Jewish holidays in the fall of 2005, the two of us attended the synagogue's Yom

\footnotetext{
${ }^{5}$ The date of Alexander's bar mitzvah was confirmed in an e-mail from him (Alexander Bernstein, e-mail to Carol J. Oja, 28 March 2008). Used by permission. Rabbi Israel Kazis, a longtime and muchloved leader of Congregation Mishkan Tefila, appears to have officiated.

${ }^{6}$ Burton Bernstein, interview with Katherine Lee, Drew Massey, and Carol J. Oja, as part of “Bernstein's Boston" seminar, Harvard University, 7 March 2006. Used by permission.
} 
Kippur (Day of Atonement) Kol Nidre service. As the service ended, we overheard people a couple of rows behind us talking about Leonard. We soon learned that the synagogue archive, in a small room below the sanctuary, is full of papers and other memorabilia relevant to the events and people that shaped Bernstein's earliest musical experiences. One container in the archive, marked "Personalities Box," contains materials about a former Jewish mayor-and about Leonard Bernstein.

As we organized the course, we built a web of connections that were essential for carrying out the project. Marie Carter and Craig Urquhart of the Leonard Bernstein Office were consistently generous in granting permission to consult documents, providing addresses of Bernstein colleagues and friends, and responding to a blitz of questions. Another key relationship was forged with the Eda Kuhn Loeb Music Library at Harvard, as well as with the university's Office for the Arts. Sarah Adams, Keeper of Harvard's Isham Library, creatively directed work on our Bernstein exhibit, and she has re-entered the project as guest editor of this volume. Liza Vick, the library's Music Reference and Research Librarian, helped the students shape initial research strategies and has since devoted endless hours to preparing the website for public access. Tom Lee and Jack Megan from the Office of the Arts produced our Bernstein Festival, and Judith Clurman of New York City and Carol Oja served as its codirectors. They flexibly and frequently reshaped the festival's program to capitalize on discoveries being made by the students. ${ }^{\text {? }}$

One of our most fundamental ties was with the Bernstein family, including Leonard's children, Jamie, Nina, and Alexander, and his brother, Burton. They participated in interviews and facilitated our access to archival materials. Mark Eden Horowitz from the Music Division of the Library of Congress assisted our students most generously in negotiating the wealth of Bernstein archival materials in Washington, D.C. Zona Hoffman, Charlotte Kaitz, and Barbara "Sis" Kazis of Congregation Mishkan Tefila helped in innumerable ways, not only with providing access to the synagogue's archive but also with helping to set up an interview session there. Several graduate students contributed work well beyond that required for the classroom, including Emily Abrams Ansari, who served as teaching fellow for the course and edited some of the materials incorporated here; Ryan Bañagale, who contributed a paper to this volume, was the lead student curator for the exhibition, and he helped organize the conference; and Shira Brettman, Elizabeth Craft, Drew Massey, and Lucille Mok, all of whom have participated in structuring the students' research into a public-access website.

We recite these names to give proper credit but also to convey a real-life sense of the advance planning and multilayered collaborations that are essential for a project

\footnotetext{
${ }^{7}$ Mounting a course of this magnitude can be an expensive undertaking. We had to work hard to raise funds on campus and thankfully were successful. Funding came from the following Harvard sources, which we acknowledge with gratitude: Innovation Fund of the Faculty of Arts and Sciences, Center for Jewish Studies, Graduate School of Arts and Sciences, and Bok Center Pilot Project in Community-Based Learning. Not many educational institutions are in a position to provide this kind of funding, however, and a project of this sort can be scaled down to fit the available resources. In our case we could have eliminated the bus tour (or done part of it via public transportation), and we could also have limited research to local interviewees and sources and to those online (that is, excluding sources from the Bernstein Collection at the Library of Congress).
} 
of this scope to take flight. In advance of the course, we also placed notices in the Jewish Advocate (a Boston newspaper), the Harvard Gazette, Harvard Magazine, and Mishkan Tefila's newsletter-all journalistic outlets that connected us to people from Bernstein's orbit. Very soon, we could barely handle the flood of e-mails and phone calls. But with the able help of Emily Abrams Ansari, we answered them all and began designing a research method.

Once the seminar began, we were fortunate to attract a lively group of nineteen graduate and undergraduate students. Our undergraduates ranged from freshmen to seniors and cut across the disciplines from music concentrators to those in biological anthropology, mathematics, social studies, and other fields. Our graduate students were primarily from the Music Department, divided between historical musicology and ethnomusicology. There were auditors as well. Early on we made a decision to privilege the process of research over any final products (such as traditional culminating papers) and to expend most of our efforts on gathering data that would be deposited in the Harvard Music Library and accessible to future researchers. Ultimately, the class unfolded on two levels, involving in-class interviews and discussion, together with independent research outside of the classroom. The latter was carried out by both individuals and small groups.

From a survey of existing documentary sources about Bernstein, as well as our new contacts, we compiled a list of individuals to invite for in-class interviews. These interviews were conducted by the students and supervised carefully by us. We drew up guidelines for conducting ethnographic and archival research, and we spent class time discussing methodology. In short, these sessions provided a terrific opportunity to teach interviewing technique. They also meant that each class session required major staging and preparation. (The seminar met once a week for three hours.) We set up blogs so that class members could contribute questions and offer critiques of one another's work. We met with each interview team beforehand to shape a strategy, and we videotaped all class sessions. The students conducting the interviews prepared transcripts of the interviews afterwards, and they also wrote field notes. All this material was pooled on the class website and later archived in the Harvard Music Library. The constant presence of a video camera in the classroom wasn't exactly a boon to spontaneity, but it was essential for documentation. From the beginning, we were aware that we were gathering primary sources of great archival value.

In tandem with these in-class interviews, independent research teams worked outside of class, yielding our other main structural component. Students clustered according to their interests, sharing interview transcripts, notes, and images of archival documents on the web. We sketched out possibilities for independent research in advance of the seminar, and students reshaped them as they worked, resulting in six general groups that subsumed major issues, venues, and institutions: 1) Family History and Networks, 2) Jewish Boston, 3) Primary and Secondary Education, 4) the Years at Harvard College, 5) Boston Compositions, Previews and Premieres, and 6) Bernstein's Broader Musical World, including the BSO, radio, jazz, and more. We alternated the in-class interviews with sessions devoted to reports from individual research teams so that all could make suggestions about their work outside of class. 


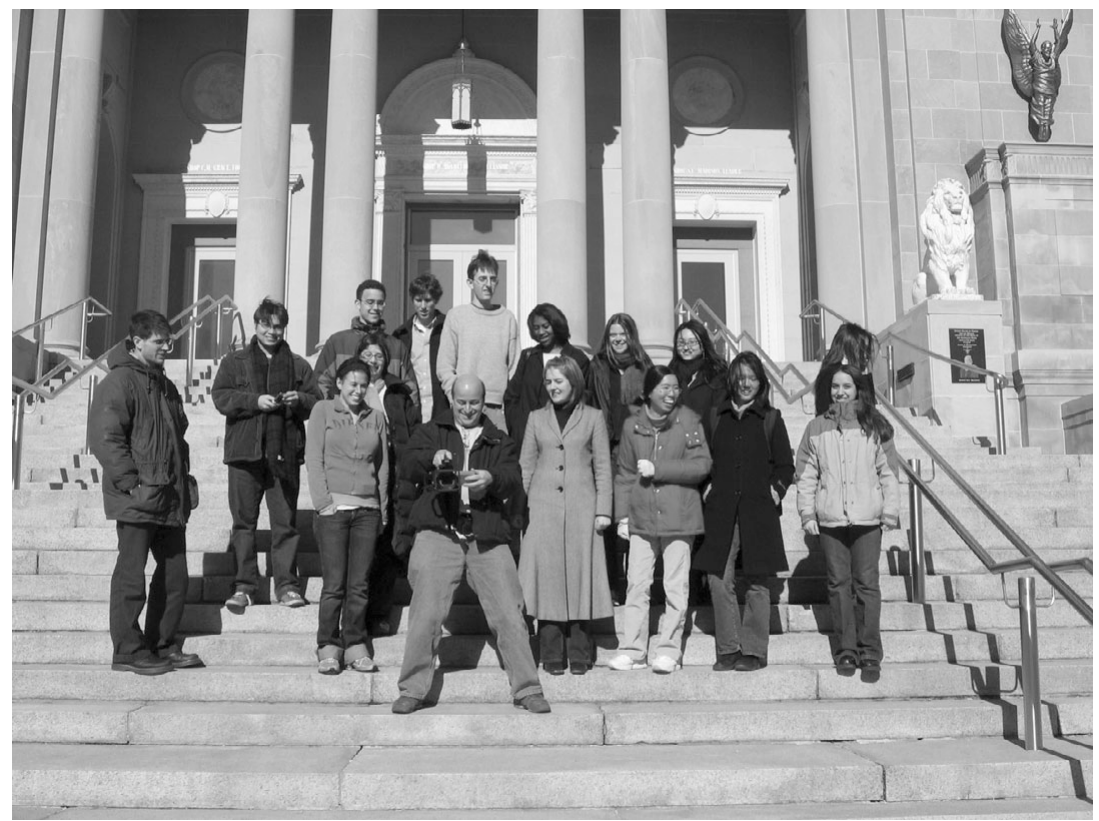

Figure 3. Students from the "Bernstein's Boston" seminar on the steps of the old home of Congregation Mishkan Tefila in Roxbury, March 2006. Far left: Drew Massey. Back row (from left): Ryan Bañagale, Giancarlo Garcia, Peter D'Elia, Nick Commins, Kara Furman, Corinna Campbell, Katherine Lee, Alex Tan. Remaining students (from left): Shira Brettman, Ayden Adler (auditor), Glenn Kinney (Harvard Media Technician), Emily Abrams Ansari (teaching assistant), Lily Yeh, Stephanie Lai, Stephanie Samuels. Photo by Scott Kominers (a member of the class). Not pictured here are Katherine Chen, Marc Gidal, Sheryl Kaskowitz, Derrick Wang, and Emily Zazulia.

In addition, we staged other special events for the group, such as an ambitious, all-day bus tour of sites associated with Bernstein, including visits to his childhood apartments and relevant institutions in neighborhoods of Boston. We both believe that the places central to a given topic need to be experienced first-hand by scholars. The bus tour entailed a great deal of preparation, both in tracking down addresses of important locations and in plotting an efficient route that stretched all over metropolitan Boston to Sharon, Massachusetts, about forty-five minutes to the southwest. We visited the grand structure in Roxbury overlooking Franklin Park where Congregation Mishkan Tefila was located during Leonard's childhood and were invited inside by ministers from the United House of Prayer, which currently occupies the building (Fig. 3). We toured the house that Sam Bernstein built in Newton in 1932 as his business flourished; we had made advance arrangements with the current residents to come inside. The class spent an hour trying to figure out which second-floor bedroom had been Leonard's and how the laundry chute had been used by him and his two siblings during childhood games. In the intervening years, Newton has gained a large Jewish population, but that wave had not yet begun in the $1930 \mathrm{~s}^{8}{ }^{8}$ Our class also had a prearranged visit to Temple

8 "Estimated Jewish Population of Brookline, Allston-Brighton, Newton," in Sarna, Smith, and Kosofsky, The Jews of Boston, 344. There the Jewish population of Newton in 1930 is given as 1,400. In 1990 it was 31,000. The movement of Jews from Roxbury to Newton and Brookline after World War II is also discussed in Paula E. Hyman, "From City to Suburb: Temple Mishkan Tefila of Boston," 
Adath Sharon, the small synagogue that Sam Bernstein helped found in Sharon, Massachusetts. There, too, we gained a sense of how Sam had been in the vanguard of balancing assimilation and upward mobility with loyalty to his Jewish immigrant roots. Although Sharon is now largely Jewish and has become a suburb of Boston, in the 1930s Sam was among the pioneers who established a small Jewish summer community there called "The Grove."

Later in the semester we staged a group interview at an "open-mic" session at Congregation Mishkan Tefila. The goal was to gain more testimony about the relationship of the Bernstein family to the synagogue. We posted a date and time in the synagogue newsletter, and the rabbi graciously announced our interview during services. A cluster of people turned up, and the intriguing stories they told stretched far beyond the walls of Mishkan Tefila, vividly illustrating the links between this congregation and musical life in greater Boston. Among those interviewed were Anita Kurland, who founded the BSO's children's concerts in the 1950s and worked with Bernstein repeatedly over the years, and Victor Alpert, a longtime librarian for the BSO who was a friend of Bernstein from their adolescence in Sharon; Alpert provided a wealth of information about Bernstein's musical activities as a teenager in Sharon.

All this activity resulted in a deluge of data, too much to be discussed here. In the remaining pages we will provide some highlights from these interviews, followed by a brief overview of some of the most exciting research findings from the student teams.

\section{Insights from Interviews}

During the course of the semester, we carried out seven in-class interviews. ${ }^{10}$ As a public figure for virtually all his adult life, Bernstein's later professional and personal activities were exceedingly well documented. Indeed, his early piano teacher and longtime personal assistant, Helen Coates, maintained elaborate scrapbooks that provided rich resources for our project. Widely read biographies by Leonard's

in The American Synagogue: A Sanctuary Transformed, ed. Jack Wertheimer (Cambridge: Cambridge University Press, 1987), 186-88.

${ }^{9}$ In his interview with our class (see note 6 above), Burton Bernstein shared some thoughts about the founding of the Jewish community in Sharon, Massachusetts: "And Sharon had a lot of people ... [who] were in very hard times during the Depression. And when better off Jews from Boston wanted to buy land there, and build houses, they said 'okay.' And even though other towns around there-Easton and Bridgewater-said 'no', Sharon said 'yes.' So that's how that community called 'The Grove' started." Burton Bernstein has published a book titled The Grove (New York: McGraw-Hill, 1961).

${ }^{10}$ Here is a complete list of people interviewed by our class, grouped by interview session: Jonathan Sarna; Harold Shapero and Sid Ramin; Harvey Tattelbaum and Judith Clurman; Burton Bernstein, Jamie Bernstein Thomas, and Nina Bernstein Simmons; Jonathan Sheffer; and (at Congregation Mishkan Tefilla) Judith Cohen, Charlotte Kaitz, Adele Picket, Barbara "Sis" Kazis, Anita Kurland, Victor Alpert, and Gerald Levinson. An additional batch of interviews was undertaken by students in a seminar on musical theater led by Oja in the fall of 2006. These interviews occurred during Harvard's Bernstein Festival and were focused on the many luminaries who participated, including Alexander Bernstein, Humphrey Burton, Grover Dale, Rob Fisher, Edward Fox, Sheldon Harnick, Carol Lawrence, Ricky Leacock, Kathleen Marshall, John Mauceri, Marni Nixon, Harold Prince, Donald Saddler, and Damian Woetzel. All have been transcribed and are deposited in the Eda Kuhn Loeb Music Library at Harvard, http://my.harvard.edu/icb/icb.do?keyword=bernstein. 
brother Burton Bernstein and, later, by biographer Humphrey Burton yielded considerable detail as well. ${ }^{11}$ But holes still exist in our knowledge of his youth, and in these interviews we sought to elicit information that might fill in the rather sketchy picture of how this composer and conductor emerged. Repeatedly, the in-class interviews positioned the young Bernstein within various communities, providing a vivid sense of how this particular celebrity was nurtured within a network of longstanding personal and professional relationships. In the process we gathered a great deal of vivid — often moving — testimony that not only brought to life memorable moments in Bernstein's world but also deepened our perspective on the overlapping Boston environments within which he was raised.

Some of the most valuable testimony came from Bernstein's childhood friends, starting with Sid Ramin, who was born one year after Bernstein and met Leonard at age twelve in Roxbury. Ramin, who became Bernstein's piano and theory student, later collaborated with him in New York City as an orchestrator, most notably for West Side Story. Ramin spoke eloquently about the dimensions of Bernstein's attachment to Boston, emphasizing that although Bernstein "just loved New York... he felt that his roots were in Boston somehow." ${ }^{2}$ Ramin recalled in colorful detail his first musical experience with Bernstein:

\begin{abstract}
Of course, I met Lenny when I was twelve years old, so that's a long time ago. ... At that time, kids (I have to call us kids) played in the street, you know, you were just down there.... There was another very good friend of mine - of ours—called Eddie Ryack.... And were all playing in front of Eddie's house. So we all went into Eddie's living room. And of course the moment Lenny saw the piano it was a magnet. And he sat down and he looked at Eddie and he said, "I'm going to teach you to play 'Good Night Sweetheart." So Eddie sat down next to Lenny and it was in the key of C, and it was so easy, so basic. And if you don't know what the song-obviously nobody in this room knows what that song is but it goes [sings] "Good Night Sweetheart, dah da da da dah da." It's as diatonic, it's as simple as anything. Eddie could not play it. And he sat there and Lenny said, "No, you've got to do this." And he [Eddie] couldn't play it.

So finally I, in a burst of bravado, said, "May I try the piece and show you how I think it?" So Eddie got up and I sat down next to Lenny, and I played it. And Lenny said the immortal words, "I think you should be my student from now on." And from that day on there was a relationship of teacher and student that never changed throughout the years. Lenny was a born teacher; I was a born listener: and I didn't—my sight reading was horrible, it still is to this day. So we were so opposite, so the opposite. But when I sat next to him at the piano, I would learn everything by rote. Lenny would play the bass part and then he would move up to the treble part, and I would repeat what Lenny showed me.... That relationship really was one that lasted until Lenny passed away. Always, it was teacher and student. ${ }^{13}$
\end{abstract}

As the interviews progressed, they began to form an interactive whole, with one individual sometimes providing details about topics in which we were interested when another could not or would not. The class became especially interested in a

\footnotetext{
${ }^{11}$ Burton Bernstein, Family Matters: Sam, Jennie and the Kids (New York: Summit Books, 1982; reprint, Lincoln, Neb.: Authors Guild Backinprint.com, 2000), and Humphrey Burton, Leonard Bernstein (New York: Doubleday, 1994). Also, the EOS Orchestra published a small book that opens up perspectives on Bernstein's student years at Harvard: see Claudia Swan, ed., Leonard Bernstein: The Harvard Years 1935-1939 (New York: Eos Orchestra, 1999).

${ }^{12}$ Sid Ramin, interview with Ryan Raul Bañagale, Emily Abrams Ansari, and Corinna Campbell, as part of "Bernstein's Boston" seminar, Harvard University, 21 February 2006. Used by permission.

${ }^{13}$ Ibid.
} 
special language called "Rybernian," which Leonard created as a child with the friend just mentioned by Ramin-Eddie Ryack. Ryack was still alive during our seminar, but too ill to participate in interviews. However, Ramin also learned Rybernian and reported that he and Leonard had spoken it together until Leonard's death:

I would see him after a concert sometimes. I would lean over and I'd give him the password. And he would absolutely-in the midst of everything, he would fall on the floor. Because you've just finished a concert, and with everyone there, and I'd just whisper to him. $\mathrm{He}$ would absolutely fall down, it was so funny. ${ }^{14}$

However, Sid declined to share any details about Rybernian. He explained:

But that was our little... secret which will remain a secret.... I can't [divulge it] and I'll tell you why. Even Jamie [Bernstein] at some point tried to finagle me into ... because I promised Lenny I would never ever do it. And we both adhered to that. It was our secret language, and we both stuck to it, and to his dying day he didn't and to my dying day I guess I won't either. It's just that we promised each other we would never do it. It was based on-I can just give you a hint-it was based on an old speech defect that an aunt of his had. It was a very weird, weird language. ${ }^{15}$

Meanwhile, over the years Leonard's brother Burton had gleaned enough knowledge of Rybernian on his own to link its development to specific members of the Bernstein family and their acquaintances, as well as to Boston speech patterns in general. Burton, not constrained by childhood promises, recalled to us that Rybernian was

an imaginary land and country, with leaders and a national anthem. [chuckles] ... I can't emphasize this enough. And it was a language that continued to live right up to his [Leonard's] last day on earth. And as far as we're concerned ... it still is around. It still is a living language. There are very few languages I think you can say that about....

The influences on this language were legion. They were mainly my father and his friends with their peculiar accents from the old world. A lot of Yiddish was thrown in. Relatives of all kinds, some outrageously funny.

And peculiarly enough, even Koussevitzky—Serge Koussevitzky, who was Lenny's mentor and spiritual father-was truly as important a source for this language as anything else. Specifically, one thing comes to mind about Koussevitzky with his accent and his lack of syntax in the English language: he confused the past tense of any verb with the imperative. And one memorable occasion was when a student conductor at Tanglewood was being very erratic and was getting all mixed up in his tempi. And 'Koussie' jumped up ... and he said, 'Took it the tempo und kept it!' and that became a basic part of Rybernian too. For instance, the all-important question in Rybernian that Lenny, Shirley, and I would ask at crucial moments was: "How you gonna did it?" That was a salute to Koussevitzky.

So [Rybernian embraced] all accents. This is again part of the humor I think of when I think of Boston. All accents were funny and derisive. It was a very derisive kind of humor. And one of the accents that was most funny to all three of us, because we had them ourselves, was the Boston accent. And it was a constant joke right up to the end for Lenny and Shirley and me. ${ }^{16}$

\footnotetext{
${ }^{14}$ Ibid.

15 Ibid.

${ }^{16}$ Interview with Burton Bernstein, note 6 above.
} 
Another memory from Sid Ramin added still more to the story of how language, and its Boston flavor, was important to Leonard Bernstein from his earliest days:

\begin{abstract}
I remember standing on a street corner with him when he was first accepted into Harvard. I remember the street [in Roxbury]. And we were standing there, and I said, "Gee Lenny, you're going to Harvard." And he said "Yes, and I'm going to develop a Harvard accent." And he did. Maybe you don't think that there's a Harvard accent but [to a person] coming from [another part of] Boston, there was.

It was a very educated, wonderful accent, which I don't have. But he had it. I guess people would call it a cultured accent today. But I remember him standing on the street, saying, "That's what I'm gonna do. I'm going to Harvard." And he zoomed in on it. ${ }^{17}$
\end{abstract}

We spent one lengthy session with the Bernstein family, including brother Burton and Leonard's daughters, Jamie and Nina. Burton, more than a decade younger than Leonard, recalled details of his own and Leonard's profound ambivalence about their father Sam's beauty supply business, which Sam had founded around 1923. ${ }^{18}$

\begin{abstract}
My father's business ... was the beauty parlor business called the Samuel J. Bernstein Hair Company, on 59 Temple Place in downtown Boston. And not only did Lenny not have a mind for business - or any thought or vague desire to go into it, even though it looked like it might be the only out - but he was also embarrassed by it, embarrassed by the whole idea of business, as indeed, I was too. My father had a small fleet of trucks that delivered beauty supplies in emergency situations to various hairdressers around the Boston area, and the trucks had emblazoned on the side, "In Boston, it's Bernstein," it said. And then on alliteratively: "The best in beauty business." And every time I'd be, you know, somewhere downtown, I'd see one of these trucks go by and cringe. [laughter] And poor Lenny did too. And also letterheads, always letterheads, for notes to teachers and things like that: "In Boston, it's Bernstein." It was just another embarrassment about the mercantile world here. ${ }^{19}$
\end{abstract}

The story of the Samuel J. Bernstein Hair Company is an important one both in interactions within the Bernstein family and for Boston's mercantile history. Beyond the information provided by Burton, we were fortunate enough to interview a relative of Leonard's who was close to others who worked for the company. This relative responded to our notice in the Jewish Advocate and talked about the high esteem in which the firm was held. The relative described class tensions within the family, which were exacerbated by tiered roles within the business. Sam hired many family members, including some of his wife's sisters, but at least one branch of the family did not feel well treated. We have permission to share this story about the company but have agreed to preserve the speaker's anonymity:

It [the Samuel J. Bernstein Hair Company] was on 59 Temple Place, which is kind of a nice area. It was a really nice place. It was a showroom and there were people that came. This was a whole very different time from now... This was a time that hairdressers would come there, to this place, and ... they would, like, wait in line.... It was a very nice business and, you know, they had the wig thing - the wig section — and it was a really big business....

You see, so Sam had this idea about family. At that point... so this would be in the '50s ... relatives really had hoped that maybe he would sell it to them. And you know Sam

\footnotetext{
${ }^{17}$ Interview with Sid Ramin, note 12 above.

${ }^{18}$ This date comes from Humphrey Burton, Leonard Bernstein, 9.

${ }^{19}$ Interview with Burton Bernstein, note 6 above.
} 
wouldn't do that. There was something about doing things for the family that, while he took in the family, it was always with the idea that the family wasn't quite good enough and didn't warrant or deserve or whatever the word is. Didn't deserve to have it. Sam, while he benefited from people working there, he never had a high regard for the family members that really pretty much devoted their lives to the Bernstein Hair Company.

You know, and when it got sold, it got sold to some outside people who actually closed up the place on Temple Place and opened up just, like, a place in Braintree that was a warehouse, and that if somebody wanted something, they would just have it shipped; but nobody came in there anymore. It wasn't like it used to be on Temple Place. It was a great place; it was a fun place to visit. They would give permanents at that time; people got permanent waves where they were attached to machines. You know what I mean? They would do this as a demo. That people would come in and they would demonstrate these, these lines of permanent waves and they'd have to sit there and they'd be attached to a machine and they got their hair permed.

So there was all kinds of really interesting things going on, and I can understand why everyone loved the business.... It really wasn't fair that this was what Sam did, but that was the way he was.... And he never saw anybody who worked for him as anybody that had the potential to, like, run the business. And, which is really too bad because of course he wanted Leonard to run it and then he wanted Burt to run it. And they all escaped very, very quickly. ${ }^{20}$

Family lore emerged along the way as well. During an interview with the Bernstein family, we asked if there were any lullabies that had been conveyed across the generations. In response, Jamie Bernstein Thomas (JBT) and Nina Bernstein (NB), joined by Burton Bernstein (BB), replied:

JBT: We have rhymes. There's “Ride away to Boston.” ... That's dandling the kid on your knee. [JBT and BB proceed to "sing" rhyme]: "Ride away to Boston. Ride away to Lynn. You better be careful or you'll fall in!" [NBS chimes in.] And then you know, you go like this with your knees [gestures] and the kid falls down.

NBS: And they always say "Again! Again! Again!"

JBT: "Ride away to Boston. Again!"

BB: All the kids.

JBT: Yeah, that I definitely remember on grandma's capacious knees.

One can only assume that Leonard himself grew up hearing this Boston rhyme so well known to his younger brother and transmitted by his parents to their grandchildren.

We also learned a great deal about Leonard's college years, both from research in the Harvard University Archives and from interviews with a few of his classmates. The noted Boston composer Harold Shapero, whom we interviewed, first got to know Bernstein when both were undergraduates at Harvard in the late 1930s. The two young men soon discovered that they shared a passion not only for music but also for baseball-and that their families lived around the corner from one another in Newton. Shapero regaled us with stories about Leonard's cavalier attitude toward attending classes and his confrontations with several famous Harvard music professors.

${ }^{20}$ Interview with anonymous source, conducted by Giancarlo Garcia and Nicholas Commins, as part of “Bernstein's Boston” seminar, Harvard University, 17 February 2006. Used by permission. 
Shapero also recalled Bernstein as an emergent professional in 1941-a year when he worked in New York, writing and arranging pop songs, before returning to Boston to set up a piano studio on Huntington Avenue near Symphony Hall. During this period he was scrambling to establish himself as a musician:

\begin{abstract}
Well, when he graduated, when he graduated college, I remember, it was a terrible trauma to him, because he had no job and his father was mad at him all the time about making a living. And Sam Bernstein would come-when we were together-Sam would come over to me and say, "What do you want me to do with this boy? You know, he's not going to make any money!" ... And, of course, his father made the biggest financial blunder of his life because he had a chance to become partners with the guy who founded Revlon and he decided against it.... So Lenny went to New York and at that point, I mean, I got agonizing postcards in the mail, you know. He was having a terrible time but what he did was latch on as a fellow that wrote the arrangement-the piano arrangements, the sheet music arrangements_ of pop songs at Witmark [Tams-Witmark] or some place like that.

And that job, which was a torture chamber for him in a way and didn't pay him very much, was a fantastic proving ground. He learned how the whole sheet music and Tin Pan Alley system worked, you see.... I don't know how to describe it. It's not so easy to write those arrangements of a pop song. It's not-they're simplified. And so he knew the métier of how to write pop songs and when he started to write musical comedies and all that stuff there he was. He had the whole thing learned. Of course he was very good and a very sharp student and all that. So that disastrous year, when he was agonizing, turned out to be a blessing in disguise. And that's almost up to- - his big breakthrough is ' 43 , isn't it? ${ }^{21}$
\end{abstract}

\title{
Revelations from Student Research Projects
}

Some of the most exciting findings by individuals in our seminar are discussed in the other papers in this volume, contributed by doctoral candidates Ryan Bañagale, Sheryl Kaskowitz, and Drew Massey. There were additional, sometimes startling discoveries, however, provided through the collective initiative of the students participating in the project. An intellectual synergy built quickly in the group, and the students facilitated one another's discoveries. Here we will discuss briefly some of these findings and quote from student entries published in the program book for our Bernstein festival. Generally, testimony in interviews and provocative archival materials generated ideas that the students pursued, and it was their outside projects that ignited the most sparks between the interviews and archival materials.

A three-woman team including Sheryl Kaskowitz, Stephanie Samuels, and Lily Yeh worked under the rubric "Jewish Boston." Samuels and Yeh largely explored the remarkable archive at Congregation Mishkan Tefila, and Kaskowitz worked at Brandeis. At Mishkan Tefila, Samuels tracked Bernstein's attendance at Hebrew School beginning at age seven and found his graduation picture from the synagogue school in $1931 .{ }^{22}$ Meanwhile, Samuels and Yeh uncovered writings and photographs that shed light on the life and career of Solomon G. Braslavsky (1887-1975), the synagogue's musical director during Bernstein's childhood. When Bernstein later inscribed a copy of the "Lamentation" from his "Jeremiah" Symphony to Braslavsky,

${ }^{21}$ Harold Shapero, interview with Ryan Raul Bañagale, Emily Abrams Ansari, and Corinna Campbell, as part of "Bernstein's Boston" seminar, Harvard University, 21 February 2006. Used by permission.

${ }^{22}$ Stephanie Samuels, in Harvard Bernstein Festival Program Book, 35. 
he wrote: "For Prof. Braslavsky, To whom I owe much, 1945."23 The depth of Braslavsky's influence on Bernstein cannot be emphasized enough, and it deserves considerable further attention by scholars (see the article by Jonathan Sarna in this issue). Braslavsky was deeply steeped in Jewish liturgical music from his youth in Kaligorka, Russia (Fig. 4), ${ }^{24}$ and he was educated beginning in 1908 at the Akademie für Musik und darstellende Kunst in Vienna as well as at the University of Vienna. ${ }^{25}$ A concert program at Mishkan Tefila, which dates from Braslavsky's years in Vienna, states that he founded the Hakoah-Orchester (Jüdischen Sinfonieorchester) in 1919 and that beginning in 1921 he conducted the Viennese Jewish Choir. ${ }^{26} \mathrm{He}$ was also a Professor of Music Theory at various colleges and secondary schools. In 1922-23 Braslavsky went to America for a concert tour, and he became Mishkan Tefila's organist and choir director in 1928. It is intriguing to speculate about whether the young Bernstein might have heard Braslavsky share memories of Vienna. Decades later-in 1970 - Bernstein began a much-celebrated engagement as guest conductor of the Vienna Philharmonic Orchestra. He had then just retired from the New York Philharmonic and was at the peak of his career. What a striking difference between Bernstein's frequent and highly publicized appearances with the city's illustrious orchestra and that of his beloved teacher, whose conducting experiences there fifty years earlier appear to have been contained within the Jewish community.

\footnotetext{
${ }^{23}$ Handwritten inscription on Leonard Bernstein, Lamentation (Finale "Jeremiah" Symphony), adaptation by F. Campbell-Watson (New York: Harms, 1945), archive of Congregation Mishkan Tefila.

${ }^{24}$ Lily Yeh found this photo at Congregation Mishkan Tefila. We have since circulated it to a cluster of specialists in Jewish traditions and received a compelling identification from Cantor Jack Ben-Zion Mendelson (Temple Israel Center, White Plains, New York), who has offered the date and location cited above. He believes the man with the beard to be Cantor Abraham Barkin (1882-1939), father of the esteemed Cantor Jacob Barkin (1914-93). Mendelson identifies the child directly in front of Barkin as Leybele Glantz, and the one on Glantz's right (with the large Star of David) as Pierre Pintchik. These last two "became among the top echelon cantors of the golden age, and bitter rivals" (email to Carol J. Oja, 24 June 2008). Georg Haber (Direktor, Jüdisches Museum Wien) has added information about the costumes worn in the photo, writing that the vestments of cantors at modern Orthodox synagogues were inspired by those of the Protestant clergy. Also, according to Haber, the Jewish star did not have a negative image before the Nazis; apparently several Jewish sports clubs used it. Haber also passed on research about Braslavsky that was done by Akiwa Zimmermann of Israel: "[Braslavsky was] conductor in the Synagogue of Uman with Cantor Abraham Barkin, came as a young man to Vienna, studied two years at the university. In 1914 he was awarded [a degree] by the k.k.Musikakademie and he started to teach music at schools. At the same time he was a teacher at the Kantorenschule, which was founded in Vienna by Jehuda Leib Miller" (e-mails to Kay Kaufman Shelemay, 25 and 26 June 2008). We are grateful to the following for vigorous brainstorming through a chain of e-mails: Georg Haber, Joshua Jacobson, Jack Mendelson, John Planer, Marsha Rozenblit, Jonathan Sarna, and Mark Slobin.

${ }^{25}$ Lily Yeh turned up a number of documents in the archive of Congregation Mishkan Tefila that give a sense of Braslavsky's story. These include the following: 1) "Boston Public Schools: Personal Record Blank for Temporary Teachers," which Brasklavsky filled out on 27 May 1938. He cited his birthplace as well as details about his education. 2) [Braslavsky], "MY COMPOSITIONS" (typescript list, undated). 3) Braslavsky's student identification card at the University of Vienna, 1911 (reproduced in Lily Yeh, Harvard Bernstein Festival Program Book, 36). 4) A black, leather-bound notebook with student notes by Braslavsky, begun in 1913.

${ }^{26}$ Concert program (Kritiken-Auszug) for "Jüdischen National Orchester und Gesangsverein in Wien," undated, archive of Congregation Mishkan Tefila. This one-page, double-sided document includes a brief biography of Braslavsky. Research by Lily Yeh.
} 


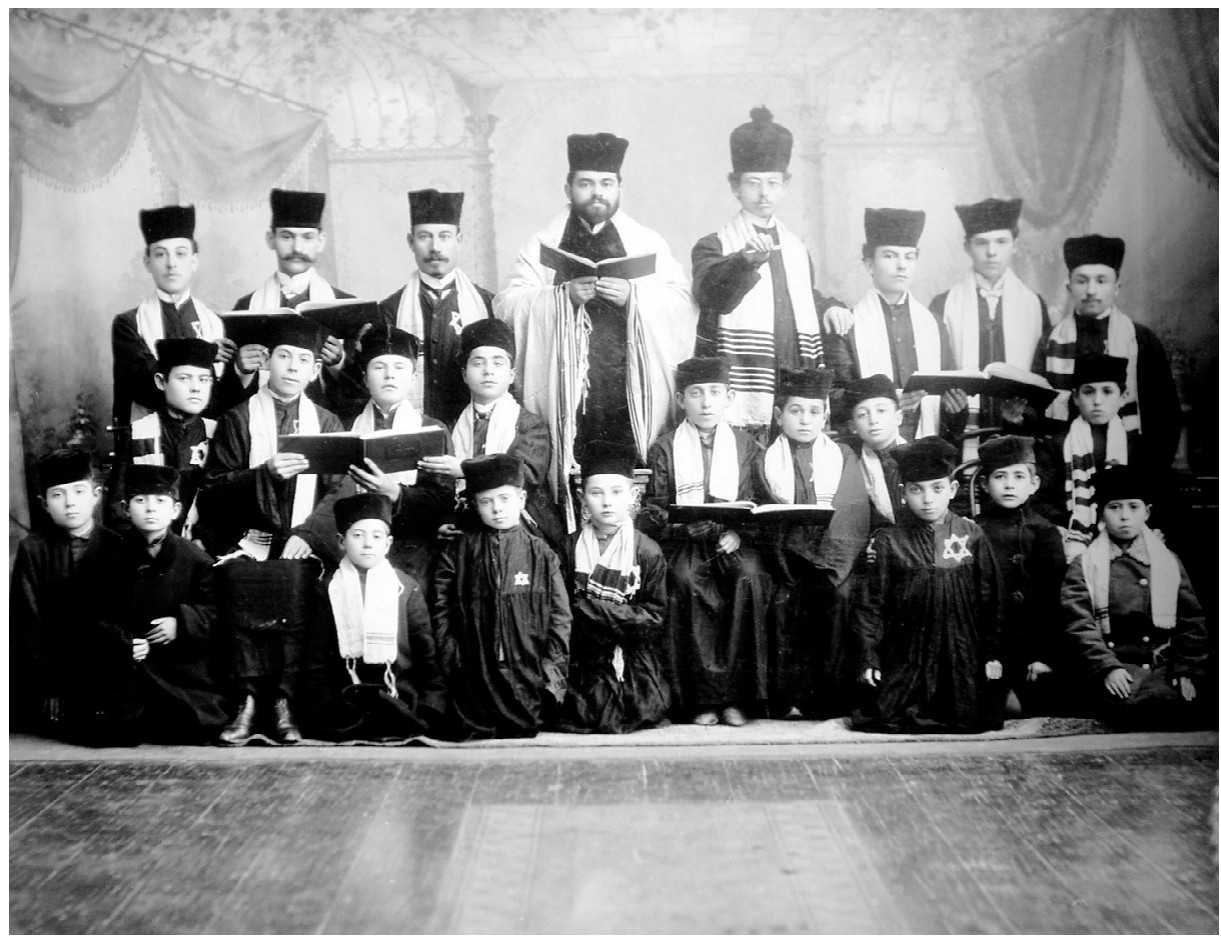

Figure 4. Solomon Braslavsky (rear center, with outstretched arm) and other Jewish musicians; Uman, Ukraine; ca. 1905. Photographer unknown. Courtesy of the Congregation Mishkan Tefila Archives.

Another seminar member, Kara Furman, became interested in the majestic Mishkan Tefila building in Roxbury, which was completed in 1925 after six years of construction (Fig. 5). ${ }^{27}$ Furman explored the musical life in that structure from its days as a synagogue through an extended period when it was the site of the Elma Lewis School of Fine Arts, beginning in 1968, then on to its current function as an African American church (United House of Prayer). ${ }^{28}$ She has suggested that "this image of the noble synagogue building highlights both the arrival and the aspirations of the Roxbury-Dorchester Jewish community, which has sometimes been called 'the risen generation'." 29

Another student cluster, which dubbed itself "Team Hair and Piano," divided its time between reconstructing a sense of the Samuel J. Bernstein Hair Company and

${ }^{27}$ In a letter to the Jewish Advocate, one of the temple's architects, J. Frederick Krokyn, described an ambitious vision fusing Jewish identity and assimilation: "The new building represents an event in the progress of the faith and is evidence of the Jewish renaissance here. Its location, in the heart of the largest Jewish population in New England, is unsurpassed in beauty and accessibility. ... The building will be ... a striking symbol to the world of our harmony with American culture and traditions" (letter published 12 March 1923). As quoted in David Kaufman, "Temples in the American Athens: A History of the Synagogues of Boston," in Sarna, Smith, and Kosofsky, The Jews of Boston, 201.

${ }^{28}$ The temple was "donated by the Jewish community" to Lewis's school, which closed in 1990. "Historical Overview; Elma Lewis School of Fine Arts Records," Archives and Special Collections Finding Aids, Northeastern University Library, Boston. <http://www.lib.neu.edu/archives/ collect/findaids/m43findbioghist.htm> (accessed 28 March 2008).

${ }^{29}$ Kara Furman in Harvard Bernstein Festival Program Book, 34. 


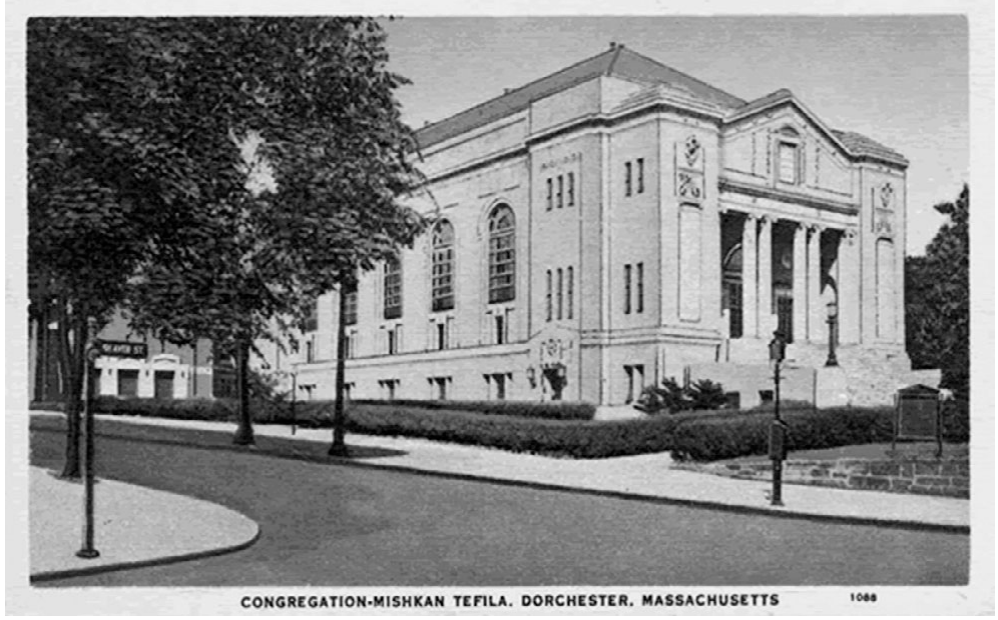

Figure 5. Postcard of Congregation Mishkan Tefila, dated 5 November 1940. Published by American Art Post Card Co., Boston, Massachusetts, photographer unknown. Courtesy of the Dorchester [Mass.] Historical Society. Research by Kara Furman.

exploring young Leonard's experiences taking piano lessons. Corinna Campbell interviewed a longtime salon owner on Mt. Auburn Street near Harvard Square, whose equipment was purchased from the Bernstein Company, and she uncovered documentation about Frederic's Permanent Wave Machine, the contraption that made Samuel Bernstein a wealthy man because he held exclusive distribution rights for it in the Northeast during the 1920s and 1930s. ${ }^{30}$

Katherine Chen from that same team constructed a tree of Bernstein's six piano teachers, tracing back through two-Isabelle Vengerova (1877-1956) and Heinrich Gebhard (1878-1963) — who had ties to Beethoven that derived from their own studies with Theodore Leschetizky (1830-1915), himself a pupil of Beethoven's disciple Czerny. ${ }^{31}$ Meanwhile, Stephanie Lai located a number of programs and other ephemera from Leonard's childhood piano recitals, including one for his first public performance in 1932 at age fourteen. ${ }^{32}$ As a student of Susan Williams at the New England Conservatory, Bernstein was the star who closed the program of eleven students, performing Cracovienne fantastique by Paderewski, Tendre aveu by Schuett, and Rhapsody in G Minor by Brahms.

Pursuing another aspect of Bernstein's educational history, a freshman-Nicholas Commins - did research in the City of Boston Archives to uncover Leonard's elementary school records, discovering that the young Leonard had attended many more schools than had been previously known. On the surface, this discovery seems like a small matter, but it opened up insights about the lives of Jewish immigrants in Boston during this period. As was common then, the Bernstein family moved

${ }^{30}$ Corinna Campbell in Harvard Bernstein Festival Program Book, 37.

${ }^{31}$ Katherine Chen, in Harvard Bernstein Festival Program Book, 42.

32 "Pianoforte Recital by Pupils of Susan Williams," New England Conservatory of Music, 30 March 1932. Archives of the New England Conservatory, Boston. Research by Stephanie Lai, reproduced in Harvard Bernstein Festival Program Book, 43. 
every year, and a new school often came with a new apartment. From kindergarten through part of second grade (1922-25), Bernstein attended the Audubon School in Dorchester. He next attended the Williams School in Roxbury, staying there through the first few weeks of third grade. Then followed two years at the Morrison School (grades 3 and 4, 1925-27). Finally he transferred in 1927 to the William Lloyd Garrison School, which was right around the corner from Congregation Mishkan Tefila in Roxbury, and he remained there until enrolling at Boston Latin. Records from the schools also show that Bernstein had quite a few female teachers with Irish surnames, bearing witness to the proximity in which Jews and the Irish lived in early-twentieth-century Boston. ${ }^{33}$

Shira Brettman, a junior, became interested in Bernstein's summertime musical productions in Sharon, Massachusetts, which he directed from 1932 onward. In Bernstein's scrapbooks Brettman located a program from 29 August 1936 for a summer production of Gilbert and Sullivan's H.M.S. Pinafore; tickets to the production cost 25 cents, and the role of "Josephine" was played by the Bernstein family maid, Lelia Jiampietro (Fig. 6). ${ }^{34}$ Brettman next used www.whitepages.com to track down phone numbers for individuals named as members of the cast. Four were still alive and sat with Brettman for interviews, which she videotaped and edited into a moving short film, which can be viewed at http://stream.fas.harvard.edu/ ramgen/permanent/bernsteinproject/bernstein_sharon.rm. ${ }^{35}$

Another freshman in the seminar, math concentrator Scott Kominers, became deeply involved in studying the doodles in Bernstein's college mathematics notebooks. Kominers's short paper exploring the dimensions and significance of those doodles is found as Appendix 2 of this article.

This overview is only the tip of the iceberg, but it gives a sense of the many imaginative directions in which the students moved and the surprisingly rich materials they discovered.

\footnotetext{
${ }^{33}$ The documents discovered by Nicholas Commins appear in Harvard Bernstein Festival Program Book (38). In Boston Boy: Growing Up with Jazz and Other Rebellious Passions (Philadelphia: Paul Dry Books, 2001), Nat Hentoff (b. 1925) recalls being beaten up by Irish kids (e.g., 24). Hentoff grew up in some of the same Jewish neighborhoods as Bernstein. Sarna discusses the tensions between Boston's Jewish and Irish populations in "The Jews of Boston in Historical Perspective" in his The Jews of Boston, 7-12.

${ }^{34}$ This program is included in "Leonard Bernstein Collection Scrapbooks," Scrapbook 1a (Washington, D.C.: Library of Congress Preservation Microfilming Program, 1999). The cost of 25 cents appears on a printed ticket for H.M.S. Pinafore (owned by Robert Potash, who was part of that production). In 2008 dollars, the sum would be about $\$ 4$. This amount was not trivial in 1936. By comparison, a ticket to the New York Philharmonic that year cost between $\$ 0.21$ and \$1.66 (Barbara Haws, Archivist and Historian for the New York Philharmonic, e-mail to Carol J. Oja, 18 June 2008.) Perhaps this comparison explains a note at the bottom of the printed program: "Proceeds to be donated to a charity." For Bernstein, these summer productions yielded a huge learning experience. In an interview about his childhood with Humphrey Burton, Bernstein later said of the previous summer (1935) in Sharon: "That is when I did the Mikado, played Nanki-Poo, [and] did an enormous production.... I learned about directing choreography, because I did the choreography in it too and how to do scenery and lighting which was pretty inadequate." Leonard Bernstein, "My Musical Childhood," interview with Humphrey Burton, 15 September 1986, [transcription], Roll 6, 1, Leonard Bernstein Collection, Library of Congress.

${ }^{35}$ Shira Brettman, Bernstein's Sharon, DVD, 2006; revised 2008.
} 


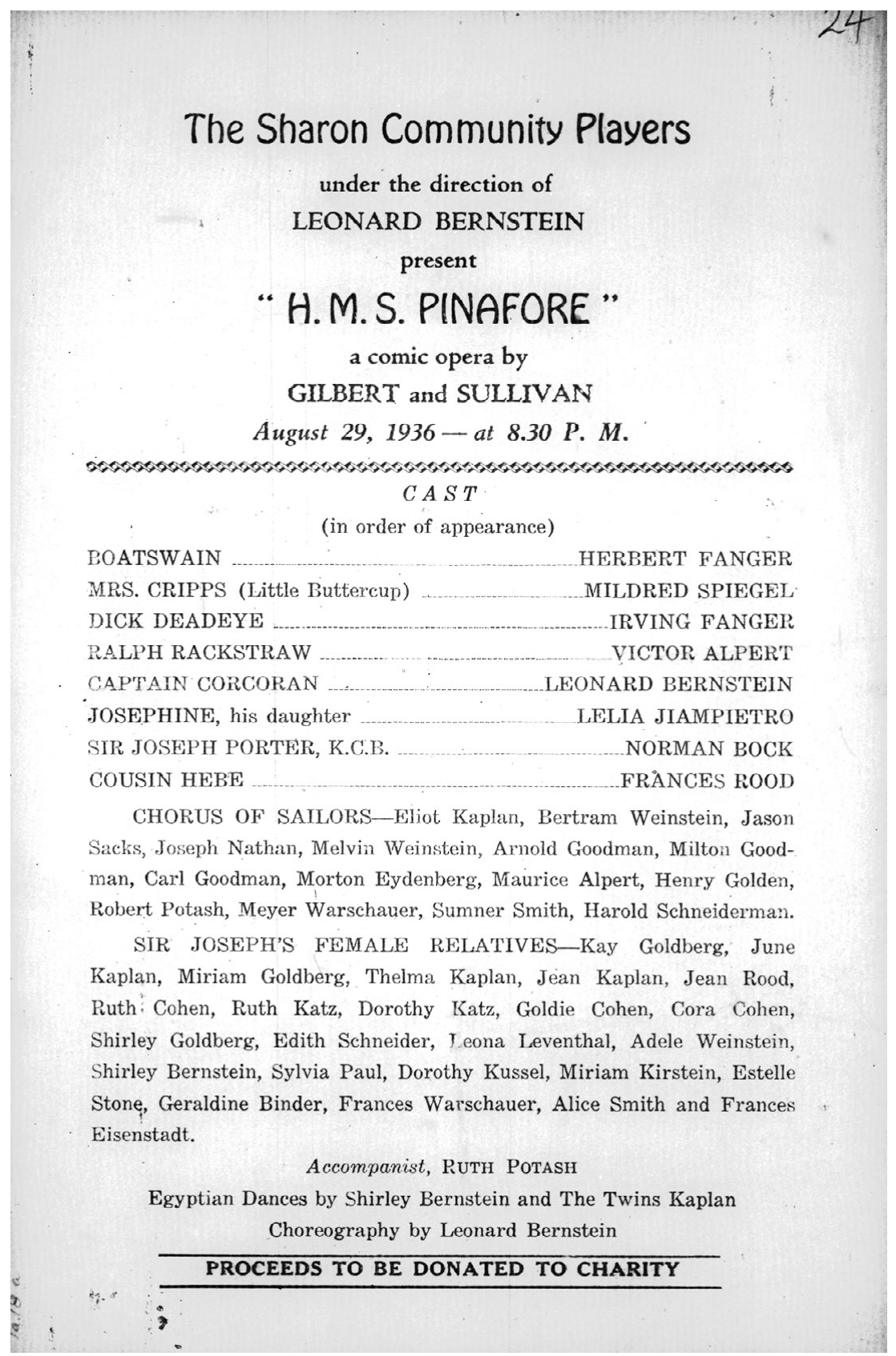

Figure 6. The Sharon Community Players' program for H.M.S. Pinafore, 29 August 1936. Leonard Bernstein Collection, Music Division, Library of Congress. Research by Shira Brettman.

\section{Community-Based Research: Rewards and Responsibilities}

Team projects are a delicate process, and we did our best to keep communication open throughout the semester to head off potential problems. We continually discussed possible outcomes with the students, being careful that all knew what might happen to their work and that all received full credit. We hoped that our own collaboration in teaching the course served as a model for the students, and 
we have been keenly aware of the need to reciprocate to the community for its support and help. The two of us, joined by a couple of students, gave a special presentation at Congregation Mishkan Tefila in early May 2006; Shira Brettman also gave a talk in Sharon at their annual Strawberry Festival in 2006; and we made sure that those who contributed memories and time got special tickets to Harvard's Bernstein Festival. All the data we gathered-interviews and transcripts of their contents, as well as documents, recordings, and ephemera discovered by research teams or presented to us by individuals — are now part of a website we are building for permanent deposit of the materials at Harvard's Music Library. We are currently working toward making that site fully searchable and hope to open sections of it soon to the public.

To study the young Bernstein, then, multiple communities were called into play-educational and religious institutions, personal networks, families, different strata of society, neighborhoods. We found ourselves struggling at moments with the tension of focusing on a star personality amid the memories of supportive family and friends. Keeping Leonard Bernstein in perspective as an individual with strengths and weaknesses has remained a central challenge.

A collaborative project-whether based in the classroom or not-needs to be rich and multifaceted. It must carry with it the potential for real findings and be of widespread interest to the participants. Yet, in the final analysis the ethical imperatives of such research determine what should be studied. One wants a project of great depth, breadth, and possibility, with which people are deeply engaged in their everyday lives; and one seeks a topic with the capacity to serve everyone well—research associates, researchers, the broader community.

In one of the most famous songs from Bernstein's West Side Story, the character Anita advises her friend Maria to keep to "one of your own kind, stick to your own kind." 36 Although in the context of the show she is warning against crossing ethnic boundaries in love (Puerto Rican/Anglo), we might consider, too, that the subdisciplines in musical scholarship tend to "stick to their own kind." When in the field, ethnomusicologists have made a habit of working with "others" different from themselves. This practice has led ethnomusicologists to work across ethnic, racial, religious, and national boundaries. But they have not worked as frequently across disciplinary divides or among musicians living closest to them. Historical musicologists, meanwhile, have their own patterns for conducting research. Most often they view scholarship as a solo flight rather than a collaborative missionboth in terms of what they study and how they do so. Individuals receive much more attention than does community-based musicianship, and a paper trail gets privileged over personal testimony. In this essay we have tried to sketch a project that intentionally cuts across boundaries in engrained methods of conducting musical scholarship.

All of us who love to study music - whether historians, ethnomusicologists, theorists, educators, or librarians_-might work to build an even more powerful and efficacious community of collaboration in our local environments. Music provides the gate of entry. We have a great deal to offer one other, because each of our fields

\footnotetext{
36 This number is "A Boy like That."
} 
has gained strong footholds in complementary areas. We surely can enhance our pedagogical practices through bringing the research process into the classroom. To do so requires some adjustments and a careful reappraisal of entrenched subdisciplinary agendas. Those of us in ethnomusicology need to be sure that we don't buy into a longstanding bias against local research. Nor should ethnomusicologists disdain the possibility that studying prominent individuals and the institutions of elites is worthwhile. Historical musicologists, meanwhile, might consider how collaborative work and ethnographic dimensions can enhance an understanding of both written sources and of the multilayered forces that inspire musical creativity and performance. At the center of this enterprise, all of us need to assume responsibility for bringing musical processes and their meanings to the public arena, guiding public discourse and performance, and setting agendas in our major national foundations, public organizations, and the world of cultural presentation.

\section{Appendix 1: Bernstein's Boston: A Timeline, compiled by Emily}

\section{Abrams Ansari}

\section{Bernstein's Boston: A Timeline}

The following timeline, compiled by doctoral student Emily Abrams Ansari, focuses on Leonard Bernstein's Boston youth and ongoing connections to the city. NonBoston-related events are in a smaller font size.

1918 Born 25 August, Lawrence, Mass. Named Louis Leonard, but known by family as Leonard. Spends first two years in Mattapan, Mass.

1920 Bernstein family moves to Allston, Mass. Sam Bernstein joins Congregation Mishkan Tefila in Roxbury (near the boundary with Dorchester).

1923 Family moves to Mattapan and then Roxbury, living in a variety of rental accommodations over the next six years.

Samuel Bernstein Hair Company is founded.

1928 First piano lessons with Frieda Karp (\$1 per lesson).

1930 Graduates from William Lloyd Garrison Grammar School, Roxbury, Mass.

Begins piano lessons with Susan Williams, New England Conservatory ( $\$ 3$ an hour).

1931 Bar mitzvah, Congregation Mishkan Tefila.

1932 Family moves to newly built house, 86 Park Ave., Newton, Mass., and purchases house in a summer colony, 17 Lake Ave., Sharon, Mass.

Family joins Temple Adath Sharon.

First public piano performance in recital of students of Susan Williams, New England Conservatory.

Shortly after, begins piano lessons with Helen Coates, assistant to Heinrich Gebhard (\$6 an hour).

Attends first orchestral concert in May: Arthur Fielder and Boston Pops (benefit for Palestine trade union movement).

1933 Buys Boston Symphony Orchestra subscription and begins attending regularly.

1934 Appears as pianist in the Grieg Piano Concerto with Boston Public School Orchestra, Roxbury High School.

Produces and stars in Carmen, with cast members in drag, Singers' Inn, Sharon, Mass.

1935 Graduates Boston Latin School. Composes class song, "All for One, and One for All."

Produces and stars in The Mikado, Town Hall, Sharon, Mass.

Legally changes his name to Leonard.

Begins piano lessons with Heinrich Gebhard (\$25 an hour).

Begins studies at Harvard University, residing in Wigglesworth House. 
1936 Produces and stars in H.M.S. Pinafore, Town Hall, Sharon, Mass.

Moves to Eliot House, Harvard.

1937 Summer job as music counselor at Camp Onota, Pittsfield, Mass., where he meets Adolph Green and produces The Pirates of Penzance and Gershwin's Of Thee I Sing; also arranges Rhapsody in Blue.

Professional debut in Ravel's Piano Concerto with the State Symphony Orchestra at Sanders Theatre, Harvard.

Meets Aaron Copland, for whom he plays Copland's Piano Variations.

1938 Becomes Music Editor for Harvard Advocate and writes criticism for Modern Music.

1939 First formal appearance as a conductor, leading his own incidental music to a student production of The Birds, at Sanders Theatre, Harvard University.

Directs and performs, from the piano, Marc Blitzstein's The Cradle Will Rock with Harvard Dramatic Club. Blitzstein attends performance.

Submits senior thesis, "The Absorption of Race Elements into American Music."

Graduates from Harvard, cum laude.

1940 Spends first summer as a student of Serge Koussevitzky, at Berkshire Music Center, Lenox, Mass.

Begins studies with Fritz Reiner at the Curtis Institute of Music, Philadelphia.

1941 Bernstein family leaves Newton to reside year-round in Sharon.

Receives diploma from Curtis Institute.

Writes incidental music for Aristophanes' Peace, produced by Harvard Student Union at Harvard.

Sets up piano teaching studio at 295 Huntington Ave., Boston.

1942 Premiere of Sonata for Clarinet and Piano, Boston.

Produces Copland's The Second Hurricane, Jordan Hall, New England Conservatory.

1943 Premiere of I Hate Music, Public Library, Lenox, Mass.

Named assistant conductor of Philharmonic Symphony Society of New York.

1944 Premiere of Symphony No. 1: Jeremiah, Pittsburgh.

Boston premiere of Symphony No. 1: Jeremiah, Boston Symphony Orchestra.

Out-of-town preview of On the Town, Colonial Theatre, Boston.

Premiere of On the Town, Adelphi Theater, New York City.

1945 Begins three-year directorship of New York City Symphony.

1948 Conducts premiere of Harold Shapero's Symphony for Classical Orchestra, Boston Symphony Orchestra.

1949 Premiere of Symphony No. 2: The Age of Anxiety, Boston Symphony Orchestra.

Conducts premiere of Olivier Messiaen's Turangalîla-symphonie, Boston Symphony Orchestra.

1951 Becomes head of Orchestra and Conducting Departments of Berkshire Music Center (through 1955).

Marries Felicia Cohn Montealegre at Congregation Mishkan Tefila.

Becomes professor of music at Brandeis University, Waltham, Mass. (through 1954).

U.S. tour with Israel Philharmonic Orchestra.

1952 Directs the first Festival of Creative Arts at Brandeis University, which includes conducting the premiere of his Trouble in Tahiti and of Marc Blitzstein's translation of Weill's The Threepenny Opera.

Birth of daughter, Jamie Anne Maria.

1953 Out-of-town preview of Wonderful Town, Shubert Theater, Boston.

Premiere of Wonderful Town, Winter Garden, New York City.

Directs second Festival of Creative Arts at Brandeis, which includes the American premiere of Francis Poulenc's Les Mamelles de Tirésias, Brandeis University.

1954 On the Waterfront, with score by Bernstein, released by Columbia Pictures.

First Omnibus television broadcast, on the sketches for Beethoven's Fifth Symphony, 1st movement.

1955 Birth of son, Alexander Serge Leonard.

1956 Out-of-town preview of Candide, Colonial Theater, Boston.

Premiere of Candide, New York City.

1957 Premiere of West Side Story, New York City.

1958 Commences eleven-year period as music director of New York Philharmonic.

Begins Young People's Concerts with New York Philharmonic.

1959 Publishes The Joy of Music (New York: Simon and Schuster). 
1962 Birth of second daughter, Nina Maria Felicia.

Publishes Leonard Bernstein's Young People's Concerts, ed. Jack Gottlieb (New York: Simon and Schuster).

1963 Premiere of Symphony No. 3: Kaddish, in Tel Aviv, Israel.

Helps with publishing music of Solomon Braslavsky, including "Unasaneh Tokev."

1965 Premiere of Chichester Psalms, New York Philharmonic.

1966 Publishes The Infinite Variety of Music (New York: Simon and Schuster).

1971 Premiere of Mass, Washington, D.C.

1973 Delivers six lectures titled The Unanswered Question as the Charles Eliot Norton Professor of Poetry at Harvard.

1976 Publishes The Unanswered Question (Cambridge, Mass.: Harvard University Press).

1982 Publishes Findings (New York: Simon and Schuster).

1983 Premiere of A Quiet Place, Houston.

1990 Dies 14 October, New York City.

Notes. This timeline draws on research undertaken by the Harvard seminar "Before West Side Story: Leonard Bernstein's Boston," which in turn was grounded in the following sources: Jack Gottlieb, Leonard Bernstein: A Complete Catalogue of his Works (New York: Leonard Bernstein Music Publishing Company, 1998); Humphrey Burton, Leonard Bernstein (New York: Doubleday, 1994).

\section{Appendix 2: "Leonard Bernstein's Doodles: Reading outside the Lines at the Library of Congress," by Scott Duke Kominers}

Often one must read "between the lines" to decipher hidden meaning or overall context within a text. But sometimes it is just as important to read outside the lines. Attempting to understand some of Leonard Bernstein's genius, I studied his course notebooks on file in the Bernstein Collection at the Library of Congress, and the most surprising finds-pages on pages of doodles-were in the margins. As a case study in the importance of probing unusual sources, I present several of Bernstein's course notebooks in Sections 1 and 2. In Section 2 I explain how my study confirms an assertion made by Bernstein's longtime friend Harold Shapero that Bernstein was not especially involved in his music classes and that "Lenny never showed up, at all" to the Music B seminar Shapero and Bernstein shared at Harvard. ${ }^{37}$ In Section 3 I discuss how the doodles and a graphology study can give unsuspected insight into Bernstein's intellect as well as shed light on aspects of his personal relationships, especially that with his father.

\section{Bernstein's High-School Geometry Notebook}

The Bernstein papers at the Library of Congress include Bernstein's geometry notebook from high school at Boston Latin School. ${ }^{38}$ Like any normal set of student geometry notes, this notebook is primarily filled with propositions and theorems.

This appendix is a based on a presentation given by the author on 14 October 2006 at "Leonard Bernstein: Boston to Broadway" at Harvard University. I thank Kay Kaufman Shelemay, Carol Oja, Lena Rivkin, Ellen Dickstein Kominers, Barbara Dickstein, Sidney Dickstein, Emily Abrams Ansari, Sarah Adams, Ryan Bañagale, Noam D. Elkies, Natalie Kirschstein, and the participants in the Harvard "Leonard Bernstein's Boston" seminar for their helpful comments and suggestions on the research and on earlier drafts of this manuscript. I also thank Ani Gevorkian and Mark Horowitz for their assistance with the images.

${ }^{37}$ Harold Shapero, interview by Emily Abrams Ansari, Ryan Raul Bañagale, Corinna Campbell, Carol Oja, and Kay Kaufman Shelemay, as part of "Leonard Bernstein's Boston" seminar, Harvard University, 21 February 2006. Used by permission.

${ }^{38}$ Leonard Bernstein, “Geometry notebook, Boston Latin School, 1932-33," in Leonard Bernstein Collection, Library of Congress, Box 69/2. 
Even in high school, Bernstein's handwriting was notably neat; he wrote in pen but also drew many diagrams in pencil with a ruler. Although the diagrams may have been drawn after class, the notes themselves were most likely copied down during class, because the arguments Bernstein recorded are presented in a structured, direct fashion without scratch-work.

With one exception the pages of geometry notes are doodle-free. This exception, however, is interesting: On the back of one of the pages, Bernstein drew a continuous, curvilinear form. The doodle is quite irregular, presented as a figure-eight repeatedly recopied without lifting the pen. ${ }^{39}$ To draw a figure of this type, Bernstein would not have needed to be looking at the page. In other words, his focus might well have been split between the drawing and a class lecture.

In the last two pages in the notebook, Bernstein recorded no notes and, instead, attempted to solve division problems he had devised, dividing two-digit numbers into large numbers. ${ }^{40}$ Although the class notes conclude before these pages, Bernstein most likely attempted the divisions during class. Indeed, they are recorded messily and irregularly_ - unusual for Bernstein's writing — suggesting that Bernstein could not give the divisions full focus at the time of writing. Bernstein never quite solved either division problem. He first attempted to divide with respect to hundreds, then, seeing that this did not produce the correct quotient, proceeded to divide out with respect to tens. ${ }^{41}$ Although neither of these attempts produced the correct answer, a continuation of the method he applied solves each problem. ${ }^{42}$ So he was on the right track!

Bernstein, a precocious, intelligent student, likely doodled out of boredom. The choice to escape geometry class by posing and solving mathematics problems seems surprising, and the repetition of similar attacks to the division problems indicates process-oriented thinking, as well as tenacity. ${ }^{43}$

\section{Bernstein's College Course Notes}

Further doodles pepper Bernstein's college coursework, and these documents are also housed at the Library of Congress. Like the division doodles, the college doodles often follow themes and demonstrate process-oriented thinking. For example, such doodles appear in the margins of a piano trio composed at Harvard and in a leatherbound book comprising many of his Harvard course notes. ${ }^{44}$ In them Bernstein

39 Ibid.

40 Ibid.

${ }^{41}$ In a sense Bernstein was approximating the correct quotient. He first treated hundreds as the basic units of arithmetic in the numerator of the long division. Then, after multiplicatively verifying that this did not produce the correct answer, Bernstein attempted the same process using tens as the basic units of arithmetic.

${ }^{42}$ In essence, Bernstein obtained the correct nonzero digits of the quotient but, having chosen the wrong basic arithmetical units, he was unable to correctly determine the number of zeroes that should separate those digits. Thus, Bernstein's approach would produce the correct quotient if ones were treated as the basic units of arithmetic.

${ }^{43}$ This conclusion builds on the observations of Lena Rivkin, telephone interview by Kay Kaufman Shelemay, Carol Oja, and the author, Cambridge, Mass., 6 July 2006. Used by permission.

${ }^{44}$ Bound notebook containing Harvard class notes on English, philosophy, and music, in Leonard Bernstein, "Harvard class notes: English, Philosophy, Music, Comparative Literature, 1938-39," Leonard Bernstein Collection, Library of Congress, Box 70/5. 


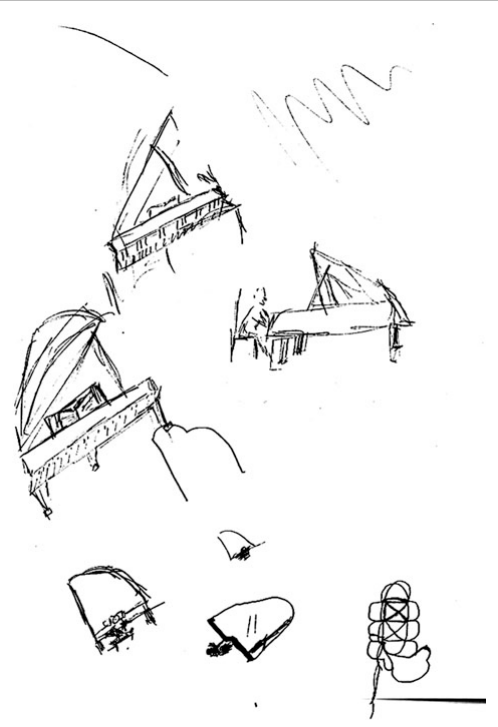

Figure 7. A presumed self-portrait of Bernstein at the piano, part of a series of piano drawings found on the back of a page of Bernstein's notes from a course in comparative literature, in Leonard Bernstein, "Harvard class notes: English, Philosophy, Music, Comparative Literature, 1938-39." Leonard Bernstein Collection, Library of Congress, Box 70/5. By permission of The Leonard Bernstein Office, Inc.

exhibited a fancy for drawing faces, both male and female. In many cases several faces were drawn as variations on a primary theme. The doodles of faces are joined by a variety of images, described in more detail below, which include objects, numbers, and signatures. All are united by multiple repetitions of each image.

Bernstein also drew doodles on the backs of loose pages from his notes for a class in comparative literature. ${ }^{45}$ These doodles exhibit progressions on categories and themes, focusing on pianos and leaves. The piano drawings are detailed, and one, pictured in Figure 7, likely contains a self-portrait. The leaf doodles are drawn less carefully and exhibit a touch of humor: a misdrawn shape is labeled "almost a pinecone."

In other doodles Bernstein practiced his signature, writing out both his full name and his initials in different fonts. These signatures would often be repeated to fill the margins of pages, and they were sometimes transposed: "Bernstein Leonard" in place of "Leonard Bernstein."

Many of Bernstein's doodles are geometric, as in Figure 8; others are mathematical. Many exhibit sharp attention to detail and symmetry, even if drawn in narrow margins. It appears that Bernstein actively considered some of his doodles to be "geometric": one image is accompanied by text declaring, "intellect is yours in this geometric world." 46

Overall the prevalence of these structured designs in Bernstein's doodles suggests that he was a logical, analytic thinker. ${ }^{47}$ The degree of detail in these designs is

\footnotetext{
${ }^{45}$ Ibid.

${ }^{46}$ Bound notebook containing Harvard class notes on English, philosophy, and music in Leonard Bernstein, "Harvard class notes," 233.

${ }^{47}$ Again, this conclusion follows the observations of Lena Rivkin, in the telephone interview cited in note 43 above.
} 


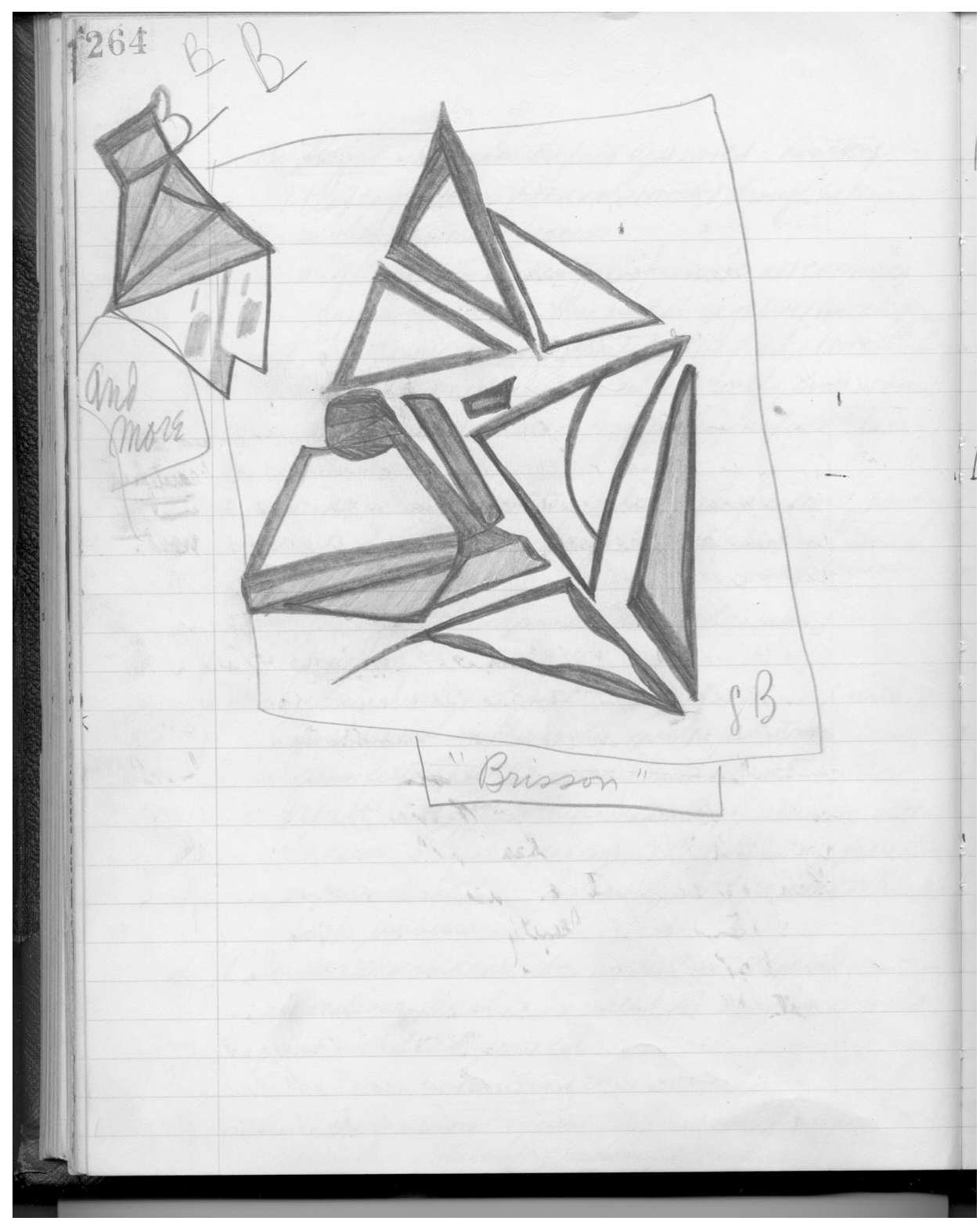

Figure 8. These geometric designs appear on page 264 of the bound notebook containing Leonard Bernstein's Harvard class notes on English, philosophy, and music, in Leonard Bernstein, "Harvard class notes: English, Philosophy, Music, Comparative Literature, 1938-39." Leonard Bernstein Collection, Library of Congress, Box 70/5. By permission of The Leonard Bernstein Office, Inc. The second image is entitled "Brisson," presumably named after Bernstein's college roommate, Norman Harold Brisson.

indicative of both his focus and his attention to detail, both of which are also apparent in his musical work.

Bernstein's notes were likely taken during lectures, as he sometimes wrote freeflowing, lecture-related comments in the margins. Although most of the notes were verbatim transcriptions of lectures written fairly legibly in Bernstein's cursive, the 
notes from music classes are astoundingly sparse. It appears that Bernstein rarely took notes in those classes, if he even attended. This concurs with Harold Shapero's assertion, quoted at the opening of this appendix, that Bernstein skipped many music classes. ${ }^{48}$ Indeed, the sections of the notebooks that Bernstein set aside for music classes are nearly note-free.

\section{Grasping Genius through Graphology}

A representative sample of Bernstein's handwriting and doodles was studied by Ms. Lena Rivkin, a qualified graphologist with special expertise in the analysis of doodles. Analyzing both Bernstein's handwriting and doodles, Rivkin offered additional insight into the significance of the writing both "inside and outside" the lines of the course notes. ${ }^{49}$ Rivkin observed that the rhythmic, fluid flow of Bernstein's writing matches naturally with his musical talent. The flourish with which he crafts his letters reflects his penchant for the dramatic.

According to Rivkin, an examination of Bernstein's handwriting's "upper zone," used to evaluate mental perceptions and intellectual aspirations, suggests strong ambitions and imagination. The "middle zone" of Bernstein's handwriting is suggestive of skill in interpersonal interactions and of an ability to adapt to everyday life issues. The "lower zone" reveals Bernstein's biological imperatives—strong sex drive, physical activity, and release or repression of anger. The scale and precision of Bernstein's writing reveal his attention to detail. The strong rightward movement indicates Bernstein's goal direction, confidence, and perseverance.

Finally, the capital "I" formations and exaggerated length of the upper zone letters in Bernstein's writing led Rivkin to conclude that Bernstein had "unfinished business" with his father figure. She made this strikingly accurate observation without any prior knowledge of Bernstein's family relationships.

Turning to Bernstein's doodles, Rivkin closely studied page 294 of Bernstein's 1938-1939 class notebook, pictured in Figure 9. ${ }^{50}$ This one page captures good examples of several recurrent themes.

In the upper left-hand corner of page 294, Bernstein wrote all the permutations of the number 294, clearly inspired by the page number. Permutations, of course, are a very mathematical notion. Rivkin observed that Bernstein's precision in writing numbers in addition to his penchant for geometric doodles indicates interest in math and calculation, as well as problem solving. This assertion is supported by Bernstein's attempts to calculate complicated divisions in high school.

${ }^{48}$ Harold Shapero, interview cited in note 37 above.

${ }^{49}$ Lena Rivkin, telephone interview cited in note 43 above. Graphology is the study of handwriting as an indicator of personality traits. Rivkin is a professional graphologist who advises major companies, universities, and government agencies on interpreting the psychological makeup of a person through handwriting and doodles. See $<$ http://www.abouthandwriting.com/index.php $>$ (accessed 25 October 2008). I thank Hedy Bookin-Weiner, Ph.D., certified graphoanalyst, for her guidance in this project.

${ }^{50}$ Bernstein, "Harvard class notes," 294; see also Scott Duke Kominers, "Leonard Bernstein Doodled Regularly," reproduced in Harvard Bernstein Festival program book, 41. 


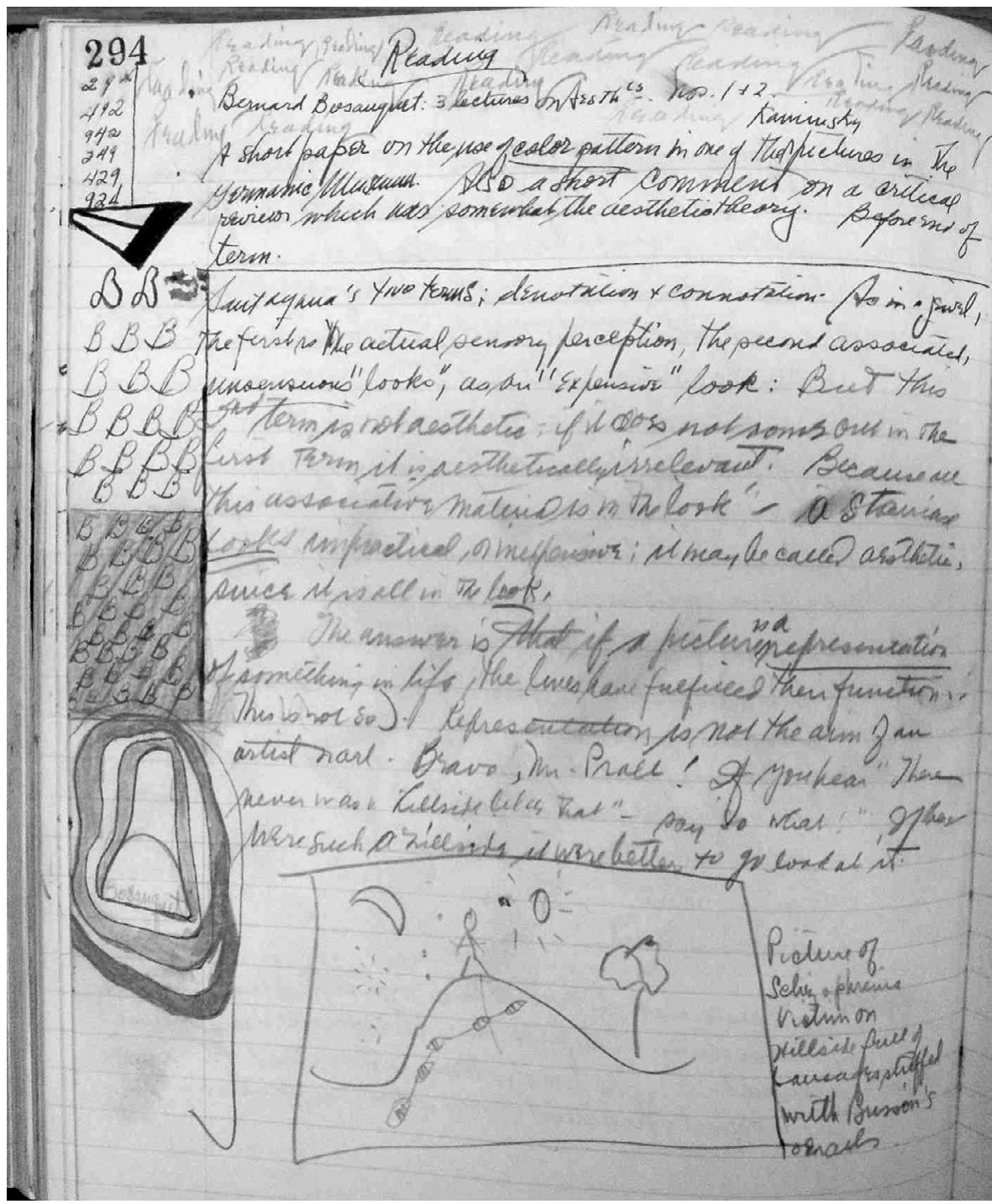

Figure 9. Page 294 of the bound notebook containing Harvard class notes on English, philosophy, and music, in Leonard Bernstein, "Harvard class notes: English, Philosophy, Music, Comparative Literature, 193839." Leonard Bernstein Collection, Library of Congress, Box 70/5. Photograph by Ani Gevorkian. By permission of The Leonard Bernstein Office, Inc.

Immediately beneath the permutations of 294 is a geometric design, beneath which Bernstein practiced the letter "B" repeatedly and added a titled stick-figure drawing on the bottom of the page. The repeated " $\mathrm{B}$ "s were given specific placement delineated by a thick line, as were the permutations and the stick-figure drawing. ${ }^{51}$ Rivkin identified Bernstein's practicing of initials and his signature as a release of stress and outside tension. The repetition of the signature also clearly indicates Bernstein's interest in himself.

${ }^{51}$ Ibid. 


\section{Conclusion}

Bernstein's doodles offer a fresh glimpse into his cognitive process, as well as into aspects of his personality and emotional life. By provoking us to read outside the lines, the doodles not only provide insight into Bernstein's analytic thinkingincluding his repeated, perhaps obsessive, efforts to perfect each and every image, however insignificant-but they also underscore in a powerful way often-cited accounts about his conflicted relationship with his father. Taken as a whole, these doodles open a window on the workings of Bernstein's mind, illuminating private domains generally inaccessible despite the very public nature of his personal life and professional career.

\section{References}

Adler, Ayden. "'Classical Music for People Who Hate Classical Music': Arthur Fiedler and the Boston Pops, 1930-1950.” Ph.D. diss., University of Rochester, 2007.

Archives, City of Boston, Boston, Massachusetts.

Archives, Congregation Mishkan Tefila, Chestnut Hill, Massachusetts.

Archives, New England Conservatory of Music, Boston, Massachusetts.

Bernstein, Burton. Family Matters: Sam, Jennie and the Kids. New York: Summit Books, 1982; reprint, Lincoln, Neb.: Authors Guild Backinprint.com, 2000.

- The Grove. New York: McGraw-Hill, 1961.

Bernstein, Leonard. Leonard Bernstein Collection, Library of Congress. Some materials from here are available online through the American Memory Project, Library of Congress.

- Leonard Bernstein Collection Scrapbooks [microform]. Washington, D.C.: Library of Congress Preservation Microfilming Program, 1999.

—. "My Musical Childhood," interview with Humphrey Burton, September 15, 1986, [transcription] Roll 6, 1. Leonard Bernstein Collection, Library of Congress.

Burton, Humphrey. Leonard Bernstein. New York: Doubleday, 1994.

Hentoff, Nat. Boston Boy: Growing Up with Jazz and Other Rebellious Passions. Philadelphia: Paul Dry Books, 2001.

Hyman, Paula E. "From City to Suburb: Temple Mishkan Tefila of Boston.” In The American Synagogue: A Sanctuary Transformed, ed. Jack Wertheimer, 186-205. Cambridge: Cambridge University Press, 1987.

Leonard Bernstein - Boston to Broadway: Concerts and Symposia at Harvard University, Carol J. Oja and Judith Clurman, directors. Emily Abrams Ansari, program book editor. Cambridge, Mass.: Office for the Arts at Harvard and Harvard University Music Department, 2006.

Oja, Carol J. "Filming the Music of Williamsburg with Alan Lomax." Institute for Studies in American Music Newsletter 23/1 (Fall 2003): 1-2, 12-13.

Sarna, Jonathan D., Ellen Smith, and Scott-Martin Kosofsky, eds. The Jews of Boston. Revised edition. New Haven, Conn.: Yale University Press, [1995] 2005. 
Shelemay, Kay Kaufman. "Together in the Field: Team Research among Syrian Jews in Brooklyn, New York.” Ethnomusicology 32/3 (1988): 369-84.

—. "Toward an Ethnomusicology of the Early Music Movement: Thoughts on Bridging Disciplines and Musical Worlds.” Ethnomusicology 45/1 (Winter 2001): 1-29.

Swan, Claudia, ed. Leonard Bernstein: The Harvard Years 1935-1939. New York: Eos Orchestra, 1999. 